\title{
EFSUMB Guidelines on Interventional Ultrasound (INVUS), Part III Abdominal Treatment Procedures (Short Version)
}

\section{EFSUMB Leitlinien interventioneller Ultraschall (INVUS), Teil III Ultraschall-geführte therapeutische Interventionen (Kurzversion)}

Authors

Affiliations
C. F. Dietrich ${ }^{1,7}$, T. Lorentzen ${ }^{2}$, L. Appelbaum ${ }^{3}$, E. Buscarini ${ }^{4}$, V. Cantisani ${ }^{5}$, J. M. Correas ${ }^{6}$, X. W. Cui ${ }^{1,7}$, M. D’Onofrio ${ }^{8}$, O. H. Gilja ${ }^{9}$, M. Hocke ${ }^{10}$, A. Ignee ${ }^{1}$, C. Jenssen ${ }^{11}$, A. Kabaalioğlu' ${ }^{12}$, E. Leen ${ }^{13}$, C. Nicolau ${ }^{14}$, C. P. Nolsøe ${ }^{2}$, M. Radzina ${ }^{15}$, C. Serra ${ }^{16}$, P. S. Sidhu ${ }^{17}$, Z. Sparchez ${ }^{18}$, F. Piscaglia ${ }^{19}$

Affiliation addresses are listed at the end of the article.

Key words
guideline
ultrasound guidance
abscess
hepatocellular carcinoma
liver metastases
radiofrequency ablation
drainage
safety

Bibliography

Dol http://dx.doi.org/ 10.1055/s-0035-1553965 Published online: 2016 Ultraschall in Med 2016; 37: 27-45 @ Georg Thieme Verlag KG Stuttgart · New York . ISSN 0172-4614

\section{Correspondence}

\section{Prof. Dr. med. Christoph F.}

\section{Dietrich}

Medizinische Klinik 2, Caritas Krankenhaus Bad Mergentheim Uhlandstr. 7

D-97980 Bad Mergentheim Germany

Tel.: ++49/(0)7931/58-22 01/ 2200

Fax: ++49/(0)7931/582290

Christoph.dietrich@ckbm.de

\section{Abstract \\ $\nabla$}

The third part of the European Federation of Societies for Ultrasound in Medicine and Biology (EFSUMB) Guidelines on Interventional Ultrasound assesses the evidence for ultrasound-guided and assisted interventions in abdominal treatment procedures. Recommendations for clinical practice are presented covering indications, contraindications, safety and efficacy of the broad variety of these techniques. In particular, drainage of abscesses and fluid collections, interventional tumor ablation techniques, interventional treatment of symptomatic cysts and echinococcosis, percutaneous transhepatic cholangiography and drainage, percutaneous gastrostomy, urinary bladder drainage, and nephrostomy are addressed (short version; a long version is published online).

\section{Introduction}

\section{$\nabla$}

This is the third of three guidelines (parts I - III) within the framework of the European Federation of Societies for Ultrasound in Medicine and Biology (EFSUMB) Guidelines on Interventional Ultrasound describing ultrasound (US)-guided percutaneous diagnostic and therapeutic interventions of the abdomen. Part III deals with the indications and clinical impact of US-guided therapeutic interventions and gives evidence-based recommendations for the safety and efficacy of these techniques using the available evidence at the time of manuscript preparation. It is complemented by guidelines on general aspects of US-guided interventions (part I) [1] and US-guided diagnostic interventions (part II) [2]. In addition, EFSUMB also will publish guidelines on the use of diagnostic and therapeutic endoscopic ultrasound $[3,4]$ and ultrasound-guided vascular interventions [5].

\section{Zusammenfassung \\ $\nabla$}

Der dritte Teil der Leitlinien der European Federation of Societies for Ultrasound in Medicine and Biology (EFSUMB) zur interventionellen Sonografie im Abdomen bewertet die Evidenz für transkutane sonografisch gestützte und assistierte therapeutische Interventionen im Abdomen. Auf der Grundlage publizierter Daten werden zu Indikationen, Kontraindikationen sowie zur sicheren und effizienten Durchführung Empfehlungen für die klinische Praxis gegeben. Berücksichtigung finden die sonografisch geführte Drainage von Abszessen und Flüssigkeitsansammlungen, Tumorablationstechniken, transkutane Zystensklerosierung symptomatischer Zysten und der Echinokokkose, die perkutane transhepatische Cholangiografie und Drainage, die perkutane Gastrostomie, die Harnblasenpunktion und Drainage sowie die Nephrostomie (Kurzversion; eine Langversion ist online publiziert).

Methods of guideline development are described in the introduction to the EFSUMB Guidelines on Interventional Ultrasound [6]. Levels of evidence (LoE) and grades of recommendations (GoR) have been assigned according to the Oxford Centre for Evidence-based Medicine criteria (March 2009 edition) [http://www.cebm.net/oxford-centre-evidence-based-medicine-levels-evidence-march-2009].

\section{Local ablative procedures \\ $\nabla$}

\section{Introduction}

Local ablative procedures play a key role in the management of patients with malignancies, primarily with hepatocellular carcinoma (HCC), but also with metastases [7-10]. 


\section{Treatment intention}

Local ablative procedures can be classified according to the treatment intention as curative or palliative [11,12].

\section{Curative intention}

Tumor ablation is usually performed with curative intent. This applies mainly to small HCCs $(\leq 5 \mathrm{~cm})$, as well as to colorectal liver metastases [12 - 18]. The decision for local ablation over resection should take into account data such as the patient's age, co-morbidities, normal parenchymal reserve and tumor distribution inside the liver, as well as the risks for metachronous tumor growth, and all these should be weighed against the invasiveness of the procedure [11].

\section{Recommendation 1}

HCC ablation should be preferably performed with curative intent (LoE 1a, GoR A). Strong consensus (100\%).

\section{Palliative strategy}

The main indication for palliative treatment of liver tumors is metastatic neuroendocrine tumor load. Other primary [19] and secondary liver tumors may also be treated [11, $20-27]$.

\section{Combined treatment options}

With multiple liver metastases (commonly colorectal) not suitable for surgical resection because of their number or location (e. g., proximity of vascular or biliary structures), a combined approach should be considered [28].

Ablation in conjunction with resection is increasingly used as a parenchyma-sparing curative strategy that combines effective ablative treatment of small tumors with resection of large tumors, for which ablation is less effective [29-36]. Similar concepts can be applied to hepatocellular carcinoma (HCC) in a cirrhotic liver, when extensive surgical sacrifice of the parenchyma must be avoided.

\section{Recommendation 2}

Ablation in conjunction with resection may be considered as a parenchyma-sparing curative strategy (LoE 2a, GoR B). Strong consensus (100\%).

\section{Hepatocellular carcinoma (HCC)}

The treatment options for HCC in a cirrhotic liver are transplantation, surgical resection, local ablative therapies, transarterial chemoembolization (TACE), radioembolization with Yttrium90 loaded beads (transarterial radioembolization) (TARE), and, in cases of advanced disease, systemic therapy with sorafenib (Nexavar $\left.{ }^{\circledR}\right)$. Image-guided percutaneous ablation therapies, such as radiofrequency ablation (RFA) [37-39], percutaneous ethanol injection (PEI) [40 - 42] and microwave ablation [43], have been performed mainly with small HCCs, according to the Milan criteria [44]. These are potentially curative, minimally invasive, and repeatable in case of recurrence [45].

\section{Local ablative treatment techniques for HCC}

Size of tumors

As a single RFA needle usually coagulates a region of about $2 \mathrm{~cm}$ in diameter, potentially non-spherical (depending on the RF sys- tem) multiple sequential insertions may be required to achieve a safety margin.

To overcome this limitation, multi-needle systems have been introduced for simultaneous ablations and stereotactically guided RFA [46-49]. There is no accepted maximum tumor size that can be ablated in a single session but the size is generally in the 4 to $5 \mathrm{~cm}$ range. The ablated zone should encompass the treated tumor and a circumferential margin of $5-10 \mathrm{~mm}$ around the tumor [50].

Location of tumors

HCC tumors in a subcapsular location or adjacent to the gallbladder have a higher likelihood of incomplete ablation [51] or major complications [52 - 54].

To reduce the number of complications, attention must be paid to vulnerable structures close to the tumor or the ablation zone. This applies to the porta hepatis, gallbladder, stomach, small intestine and colon, all of which are particularly sensitive to thermal damage $[55,56]$. In case of subdiaphragmatic lesions, pulmonary, pleural or cardiac heat damage might occur, usually with only minor clinical significance $[57,58]$.

\section{Number of tumors}

The maximum number of tumors that can be ablated in a single procedure is not clearly defined, but ranges from 3 to 5 in most centers [11]. Overall survival is best for patients with solitary tumors, intermediate for those with 2 to 3 tumors, and worst for those with $\geq 3$ tumors [59].

\section{Recommendation 3}

The maximum recommended diameter of HCC lesions treatable with thermal ablation is generally considered below or equal to $5 \mathrm{~cm}$, although optimal results are obtained in lesions $<3 \mathrm{~cm}$ (LoE 2b, GoR B). Strong consensus (100\%).

\section{Recommendation 4}

The ablation zone should aim to extend at least $5 \mathrm{~mm}$ beyond the visible borders (LoE 3a, GoR B). Strong consensus (100\%).

\section{Recommendation 5}

In lesions close to large vessels and heat-sensitive structures, alternative or additional techniques should be considered (LoE 3a, GoR B). Strong consensus (100\%).

\section{Recommendation 6}

Three to five HCCs are the recommended maximum number of lesions in a single session that allows percutaneous ablation with curative intent (LoE 2a, GoR B). Strong consensus (100\%).

RFA versus surgical resection in small HCCs

There is inconclusive evidence as to whether RFA is as effective as surgical resection as the first-line treatment for patients with small, solitary HCCs [50, 51, 53 - 56, 60 - 63]. A systematic review of 8000 patients [64] with a current Cochrane analysis [65] reported uncertainty regarding the question of the impact of RFA versus surgery. However, a more recent meta-analysis, published 
after the Cochrane analysis [66], showed that there were differences in age and liver function between patients with early HCC submitted to either RFA or resection. When the analysis was corrected for these parameters, no survival differences were observed between RFA and surgery in single HCCs $<2 \mathrm{~cm}$ or $2-3$ HCC tumors $<3 \mathrm{~cm}$, whereas surgery resulted in a longer survival in the case of single HCCs measuring $2-5 \mathrm{~cm}$ [66]. Mortality and morbidity rates of RFA have been reported to be $0-1.5 \%$ and $0.9-7.9 \%$, respectively [67 -72$]$.

\section{Percutaneous ethanol injection (PEI)}

PEI was the first ablative procedure, initially reported in the early 1980 s $[40,41,73]$.

The procedure is inexpensive and safe, with low mortality and morbidity $(0-3.2 \%$ and $0-0.4 \%$, respectively) [74-76]. Even though RFA has replaced PEI [38, 77, 78], PEI can be offered in small HCCs, mainly those for which RFA is not feasible due to tumor location.

\section{RFA versus PEI}

Randomized controlled trials comparing RFA with PEI demonstrate that RFA is superior to ethanol injection in terms of treatment response, number of sessions, recurrences, and overall survival [77-83] as further supported by meta-analyses [65, 82, 84]. The efficacy of the methods is similar for tumors $\leq 2 \mathrm{~cm}[38,77,78$, 85]. Meta-analyses, including randomized controlled trials (RCTs), confirmed that treatment with RFA offers a survival benefit as compared to PEI in tumors $>2 \mathrm{~cm}[82-84,86,87]$. RFA has a slightly higher rate of major complications $(4 \% ; 95 \% \mathrm{CI}, 1.8-6.4 \%$ ) as compared to PEI $(2.7 \%$; $95 \% \mathrm{CI}, 0.4-5.1 \%)$ [52, 79, 81, 87]. The best results obtained in series of HCC patients treated by RFA provided 5-year survival rates of $40-70 \%$ or higher in select groups of patients $[47,67,88]$. The best outcomes have been reported in Child-Pugh A patients with small $(<2 \mathrm{~cm})$ single tumors $[70,89]$. Independent predictors of survival with RFA are initial complete response, Child-Pugh score, number or size of nodules, and baseline alpha-fetoprotein levels [90].

\section{Other procedures}

Percutaneous microwave ablation (MWA) was introduced into clinical practice in the $1990 \mathrm{~s}$ [43, 91 -97].

\section{Selection of ablation technique}

With PEI, local response is related to tumor size. PEI has yielded very favorable results for small encapsulated HCCs $(<2 \mathrm{~cm})[12$, 73]. HCC encapsulation by a cirrhotic liver prevents satellite nodules from being reached, leading to higher rates of local recurrence in comparison to RFA [98 - 101]).

\section{Recommendation 7}

Percutaneous ethanol injection with curative intent is an alternative to thermal ablation in encapsulated HCCs $<20 \mathrm{~mm}$ (LoE 2a, GoR B). Broad agreement (95\%).

\section{Recommendation 8}

Percutaneous ethanol injection can be an alternative in case of contraindications to thermal ablation (LoE 3b, GoR B). Broad agreement (79\%).
Selection of imaging modality (ultrasound, CT, MRI)

US is the first-line imaging modality for local ablative procedures in the liver. CT guidance can be an alternative, particularly when US guidance is not feasible anatomically or with US imaging of occult lesions [102, 103]. MRI guidance is possible but with limited availability and major costs. Local expertise and personal experience determine the modality of choice. Contrast-enhanced imaging must be available during the interventional procedure to confirm the completeness of necrosis. Fusion imaging is an alternative technique that can be used for the guidance of the procedure.

\section{Planning and monitoring ablation treatment}

Imaging plays an important role before, during and after ablation procedures. Assessment of tissue perfusion is crucial to differentiate necrotic areas from viable residual tumor. With US-and CT-guided RFA, this requires evaluation with contrast-enhanced imaging during and immediately after ablation. Contrast-enhanced ultrasound (CEUS) can provide important information for assessment during and immediately after ablation $[104,105]$ :

- assessment of the lesions to be treated by ablation (number, size, degree and homogeneity of lesion enhancement, presence of feeding vessels, to define the eligibility for treatment and the best ablation strategy)

- depiction of previously undetectable lesions with the support of fusion imaging, enabling needle/probe guidance to occult lesions

- detection of viable tumor persistence following loco-regional treatment [50]

CEUS is the most effective method to define local recurrence in a treated nodule because of its real-time capability, the intra-vascular characteristic of the contrast agent and the near-total differentiation between the displayed contrast and background information of current imaging methods [8]. CT and MRI provide better overviews of the liver and adjacent organs, which are necessary for pretreatment staging and useful to detect distant intraand extra-hepatic tumor recurrence.

\section{Complications}

Studies have established that RFA is a low-risk procedure [106 $109]$, with a mortality of $0.1-0.8 \%$ and few adverse events. Major complications occur in $2.2-11 \%$ of RFA-treated patients [ 72,106 , $110-112]$. Bleeding, infection, arteriovenous fistula formation, bile duct damage, and tumor seeding are possible complications of local ablative therapy $[11,12,18,113]$.

Thermal track ablation can potentially reduce the likelihood of tumor seeding in HCC ablation to below $1 \%$ [114 - 117].

\section{Recommendation 9}

A multidisciplinary approach to assess patients with HCC in liver cirrhosis for possible transplantation is recommended prior to alternative treatments (LoE 5, GoR D). Strong consensus $(100 \%)$.

\section{Recommendation 10}

RFA with curative intent is an alternative, more cost-effective technique in comparison to surgery in early HCC BCLC-0 (HCC $<2 \mathrm{~cm}$ ) (LoE 2a, GoR B). Strong consensus (100\%). 


\section{Recommendation 11}

RFA with curative intent should be considered as a second-line treatment in single HCCs $2-5 \mathrm{~cm}$ in Child-Pugh A patients, after the patient has been evaluated for surgical resection (LoE $2 b$, GoR B). Strong consensus (100\%).

\section{Recommendation 12}

RFA with curative intent should be considered as the first-line treatment in Child-Pugh B patients with single HCCs $<5 \mathrm{~cm}$ or in patients with 2 or $3 \mathrm{HCCs}<3 \mathrm{~cm}$ (LoE 2b, GoR B). Strong consensus (100\%).

\section{Recommendation 13}

Solitary HCCs $>3 \mathrm{~cm}$ not suitable for surgery should be considered for combined loco-regional treatments (LoE 4, GoR C). Broad agreement (95\%).

\section{Colorectal cancer liver metastases}

It is estimated that $50-60 \%$ of patients with colorectal cancer (CRC) will develop liver metastases [118]. The most successful treatment for hepatic metastases is surgical resection $[9,10,31$, $59,119-125]$. However, approximately $50-70 \%$ of these patients will develop recurrence [126].

Local ablative procedures with curative intent have a role in the management of CRC liver metastases $[9,10]$. Depending on the size of the lesions, RFA may be performed alone or combined with resection [127]. Several studies have demonstrated that RFA achieved permanent local ablation of liver metastases and a 5year survival of $24 \%$ to $43 \%$ [ $128-132$ ]. These results are comparable to surgery [31, 59, 119-125]. Local recurrence occurs more frequently after ablation than with resection $[9,10,133]$.

Two meta-analyses confirmed that surgery is superior to RFA with regard to survival outcomes in patients with resectable CRC liver metastases $[134,135]$. The first RCT on the efficacy of RFA combined with chemotherapy versus chemotherapy alone was underpowered; RFA plus systemic treatment resulted in significantly longer progression-free survival (PFS) compared with chemotherapy alone [136].

\section{Recommendation 14}

Percutaneous thermal ablation with curative intent is a second-line alternative to surgery in patients with colorectal liver metastases (LoE 2a, GoR B). Strong consensus (100\%).

\section{Recommendation 15}

The maximum diameter of metastatic lesions treatable with thermal ablation is generally considered $\leq 4 \mathrm{~cm}$, although better results are obtained in lesions $<3 \mathrm{~cm}$ (LoE 5, GoR D). Strong consensus (100\%).

\section{Recommendation 16}

The ablation zone should aim to extend at least $10 \mathrm{~mm}$ beyond the visible borders (LoE 5, GoR D). Broad agreement ( $94 \%$ ).

\section{Other liver metastases}

Percutaneous thermal ablation or PEI may be a therapeutic option for neuroendocrine liver metastases $[23,24]$.

\section{Renal malignancies treated with local ablative therapy Introduction}

Possible treatment options for renal cell carcinoma (RCC) are [137]:

- Surgery, either nephrectomy or nephron-sparing (open or laparoscopic)

- Local ablative procedures (percutaneous or laparoscopic)

c cryoablation

$\checkmark$ RFA

$\checkmark$ MWA

- Active surveillance

\section{Small masses}

Standard therapy for small RCCs is nephron-sparing surgery. Local ablative techniques have evolved into alternative procedures, showing excellent results [138].

Tumors $<4 \mathrm{~cm}$ in diameter are ideal candidates for ablative techniques. The volume to be treated should include a $5-10 \mathrm{~mm}$ safety margin [139]. Most tumors $<3 \mathrm{~cm}$ can be treated in a single ablation session. Tumors between $3-4 \mathrm{~cm}$ in diameter can also be successfully treated, although multiple ablation sessions may be required [140-148].

\section{Recommendation 17}

Patients with RCCs $<3 \mathrm{~cm}$ with significant surgical risk or requirement for nephron-sparing strategy should be considered for local ablative therapy (LoE 2b, GoR B). Strong consensus (100\%).

RCTs comparing surgery and local ablative therapy have not been performed [137, 149]. Cancer-specific survival is similar for both methods [150, 151]. The European and American Urological Associations recommend thermal ablation as a treatment option for patients with a $\mathrm{T} 1$ renal mass [152].

Local recurrence-free survival following image-guided tumor ablation is $87 \%$ [153]. The local recurrence of percutaneously performed RFA is estimated at $2.5-14 \%$ [154]. Cancer-specific survival of patients treated with RFA is comparable to patients treated with surgery [142, 152, 155]. Both cryotherapy and RFA had a higher risk of recurrence compared to partial nephrectomy [156], but re-intervention is straightforward [142].

The rate of major complications for cryotherapy is $5 \%$, which is lower than for surgery [152], the most common complication being hemorrhage [213] with $2 \%$ developing distant metastases $[152,155]$. Post-procedural ureteric strictures have also been documented [152]. Cryotherapy is preferred over RFA in central tumors in contact with the renal hilum or the ureter [157].

\section{Recommendation 18}

RCC histology should be obtained prior to ablation (LoE 4, GoR C). Broad agreement ( $81 \%)$.

CEUS can be used for surveillance after RFA of RCCs in order to detect local recurrence and to assess for liver metastases [158]. CT of the thorax and abdomen is necessary to exclude metachronous extrahepatic metastases. No RCTs have been performed [159-161]. 


\section{Recommendation 19}

Contrast-enhanced ultrasound or CT or MRI should be performed in the follow-up after RCC ablation, unless contraindicated (LoE 4, GoR C). Strong consensus (100\%).

\section{Abscess drainage \\ $\nabla$}

US-guided percutaneous drainage of abdominal abscesses is a well-established interventional procedure first described in 1974 [162] and is currently the first-line treatment approach for abdominal abscesses.

\section{Definition and classification}

Differentiation between phlegmonous inflammation and abscesses is of importance for treatment guidance. An abscess is a puscontaining confined collection, most often caused by bacteria. To be termed an abscess, the fluid has to be viscous and surrounded by an inflammatory wall that develops as a result of effective host defense [163].

\section{Recommendation 20}

Phlegmonous infections and small abscesses should be treated with antibiotics and require no drainage (LoE 5, GoR D). Strong consensus (100\%).

\section{Postoperative fluid collection}

Fluid collections present on postoperative imaging, localized or generalized ("free fluid"), are common and nonspecific which may represent different pathological entities such as hematoma, exudate, seroma, biloma, lymphocele or an abscess. Fluid seen on imaging is often not characteristic; any patient with a clinical suspicion of an abdominal abscess should have a diagnostic aspiration to guide further management. Sterile fluid collections can become infected postoperatively, requiring diagnostic aspiration and eventually therapeutic drainage.

\section{Ultrasound (US)}

US imaging is often the initial modality used in abscess delineation as it allows dynamic evaluation and real-time guidance of needling. Depending on the contents, an abscess can be anechoic, hypoechoic and even hyperechoic. CEUS can be helpful in differentiating vascularized from avascular areas [164, 165].

CT is indicated in technically limited US examinations or inconclusive results.

\section{Diagnostic aspiration}

A US-guided diagnostic puncture of a fluid collection with a fine needle or a larger needle (depending on the viscosity) can distinguish an abscess from a non-infected fluid collection.

\section{Recommendation 21}

Diagnostic aspiration of a suspected infected fluid collection is recommended (LoE 5, GoR D). Strong consensus (100\%).

\section{Puncture and drainage}

Catheter drainage versus needle aspiration

A meta-analysis of 5 RCTs comparing catheter drainage and repeated needle aspirations of liver abscesses demonstrated catheter drainage to be more effective, with higher success and shorter time to achieve clinical improvement [166]. Studies of abdominal abscesses of various etiologies have shown good results with repeated needle aspiration in simple abscesses $<5 \mathrm{~cm}$. In larger abscesses catheter drainage performed better than repeat needle aspiration [167 - 171].

\section{Recommendation 22}

Abscesses less than $5 \mathrm{~cm}$ in diameter can be treated with needle aspiration (LoE 2b; GoR B). Strong consensus (100\%).

\section{Recommendation 23}

Catheter drainage is more effective than needle aspiration in abscesses larger than $5 \mathrm{~cm}$ in diameter (LoE 1a, GoR A). Broad agreement (89\%).

Small or large catheters

No difference in outcome was seen in a study of intra-abdominal abscesses treated with 7F pigtail catheters and $14 \mathrm{~F}$ sump drain catheters [172]. Currently large catheters (>10F) should be reserved for complex abscesses containing thick pus and debris.

\section{Recommendation 24}

Catheters of $7-10 \mathrm{~F}$ in size are recommended for the treatment of most abscesses, regardless of abscess dimensions (LoE 4, GoR C). Broad agreement (90\%).

\section{Recommendation 25}

Large catheters ( $>10 \mathrm{~F}$ ) should be reserved for complex abscesses with thick contents (LoE 5, GoR D). Broad agreement (90\%).

Catheter introduction techniques: Trocar versus Seldinger Two techniques are used for the insertion of a drainage catheter: the trocar (one-step) technique and the Seldinger (two-step) technique. Both have advantages and disadvantages and can be performed with either a free-hand or needle-guided technique, depending on the preference and experience of the operator.

\section{Recommendation 26}

The trocar technique is suitable in most circumstances using catheters $\leq 10 \mathrm{~F}$ (LoE 5, GoR D). Broad agreement (93\%).

\section{Recommendation 27}

The Seldinger technique is recommended when access is difficult, for large catheters, and for catheter replacement (LoE 5, GoR D). Broad agreement (86\%). 
Single versus double lumen

Double lumen catheters are not recommended since they combine the negative features of large diameters and relatively small lumens.

\section{Recommendation 28}

Double lumen catheters are not recommended (LoE 5, GoR D). Broad agreement (94\%).

Abscess cavity extension and complexity, fistula, and contrast injection (X-ray, CEUS)

Treatment planning requires careful assessment of the size, shape, content and extent of the abscess, including identification of associated fistulas. Fistulography (or abscessography, sinography) with intracavitary injection of iodinated contrast media under CT or fluoroscopic guidance has been the recommended technique. Direct injection of US contrast agent through the needle or catheter has been reported to facilitate confirmation of correct needle or catheter position and allows evaluation of any communication between cavities in complex abscesses at the bedside [173 - 175].

\section{Recommendation 29}

Intracavitary CEUS may add value regarding needle and catheter position, cavity morphology and presence of fistulas ( $\mathrm{LoE}$ 4 , GoR C). Strong consensus (100\%).

\section{Specific organs and locations}

\section{Liver abscess}

Pyogenic liver abscesses are often the result of biliary obstruction caused by benign or malignant diseases with consequent cholangitis. For percutaneous drainage, a transhepatic access route is preferred for direct puncture to avoid spillage of pus into the peritoneal cavity. Small amebic abscesses generally respond to conservative treatment and do not require drainage, but large amebic abscesses may need drainage [176].

\section{Recommendation 30}

The origin of liver abscesses should be investigated to search for an underlying cause (LoE 5, GoR D). Strong consensus (100\%).

\section{Recommendation 31}

A transhepatic access route is recommended for the percutaneous drainage of hepatic abscesses (LoE 5, GoR D). Strong consensus $(100 \%)$.

\section{Splenic abscess}

Splenic abscesses are rare, except in immunocompromised patients. Splenic puncture or biopsy is relatively safe as documented in a meta-analysis [177].

\section{Recommendation 32}

Percutaneous splenic abscess drainage should be the first-line treatment and surgery should be performed in the case of treatment failure (LoE 4, GoR C). Broad agreement (89\%).

\section{Pancreatic abscess}

Percutaneous drainage of pancreatic abscesses is often prolonged and may require multiple catheters. The percutaneous approach offers quick access for severely ill patients. As a second stage procedure, conversion to internal drainage with an endosonographic approach should be considered.

\section{Recommendation 33}

Pancreatic abscess management is complex and often prolonged. Drainage procedures guided by transcutaneous or endoscopic ultrasound (EUS) should be considered (LoE 4, GoR C). Broad agreement ( $89 \%)$.

\section{Enteric abscess}

Abscesses are frequent complications of Crohn's disease, diverticulitis and appendicitis. In Crohn's disease, there is no study comparing percutaneous and surgical drainage of abscesses. Percutaneous drainage of Crohn's-related abscesses has a high success rate, demonstrated in several studies and is the first-line treatment [178, 179]. With early percutaneous drainage, (non-elective) surgery can often be avoided (14-85\% of patients) [179-183].

Abscesses can be detected in $15 \%$ of patients with acute diverticulitis $[184,185]$. Antibiotics successfully treat smaller abscesses $(<3 \mathrm{~cm})[184,186,187]$, but larger abscesses $(>3 \mathrm{~cm})$ require percutaneous drainage $[188,189]$. Peri-appendicular abscesses can occur either as a result of rupture of an infected appendix or post-operatively.

It is generally accepted that a peri-appendicular abscess will respond to percutaneous drainage. Leakage of enteric contents at an anastomosis may lead to abscess formation, which most often requires reconstructive surgery. Sometimes, a non-surgical approach is preferred with usage of long-term percutaneous drainage with large catheters.

\section{Recommendation 34}

Abscesses in Crohn's disease, diverticulitis and appendicitis may benefit from percutaneous drainage as the first-line strategy (LoE 4, GoR C). Broad agreement (89\%).

\section{Abscess in the lower abdomen and pelvis}

For deep pelvic abscesses, alternative puncture routes are available. Transrectal, transvaginal, transperineal and transgluteal accesses have all been shown to be useful and safe [169, 190 - 192].

\section{Recommendation 35}

US-guided drainage by transrectal, transperineal or transvaginal access is associated with a low risk of complications and should be considered for deep pelvic abscesses (LoE 4, GoR C). Strong consensus (100\%).

\section{Recommendation 36}

Use of intracavitary fibrinolytics is not routinely recommended (LoE 5, GoR D). Broad agreement (94\%). 


\section{Ultrasound-guided paracentesis}

\section{Background}

Paracentesis is performed either as a diagnostic or as a therapeutic procedure, in the presence of ascites or suspected bacterial peritonitis. Therapeutic paracentesis provides almost immediate symptomatic relief and is usually well tolerated.

\section{Technical issues}

Ascites drainage is usually easily and safely performed by inserting a 14 - 18 gauge needle (including paracentesis-specific devices) or as a one-step catheter under US guidance. Catheters can be pig-tail, they can have an internal string for internal loop fixation, or an internal balloon fixation can be used. A small bore catheter (between $5 \mathrm{~F}$ and $7 \mathrm{~F}$ ) is usually adequate.

US guidance offers real-time imaging of the needle tip and surroundings during the procedure, making it safe and effective. In most instances, US assistance (i. e., US utilized to select the best access point prior to blind needle insertion) is as safe as US guidance [193].

\section{Complications}

Paracentesis is considered a safe procedure, carrying a $1 \%$ risk of overall complications, which include leakage of ascitic fluid, local infection, abdominal wall hematomas, intraperitoneal hemorrhage, and intestinal perforation [194]. It is recommended to follow strict antiseptic practices in all patients [195]. Ultrasound guidance can reduce the risk of complications after paracentesis $[193,196]$.

\section{Recommendation 37}

Ultrasound-guided or assisted paracentesis is a low-risk and effective procedure (LoE 4, GoR C). Strong consensus (100\%).

\section{Specific considerations}

Cirrhosis

Ascites is the most common complication of cirrhosis leading to hospital admission.

\section{Albumin administration}

Large-volume paracentesis $(>5 \mathrm{~L})$ is generally an effective and safe procedure, but it does carry a risk of "postparacentesis circulatory dysfunction" (PCD).

\section{Recommendation 38}

Administration of albumin is mandatory in large-volume ( $>5$ liters) paracentesis (LoE 1a, GoR A). Strong consensus (100\%).

\section{Recommendation 39}

There are no established preprocedural threshold coagulation levels that preclude paracentesis (LoE 5, GoR D). Broad agreement $(94 \%)$.

\section{Palliative paracentesis for malignant ascites}

Malignant ascites accounts for around $10 \%$ of cases and occurs with a variety of neoplasms [197]. Large amounts of ascites can cause increased abdominal pressure with pain, dyspnea, loss of ap- petite, nausea, and reduced mobility. Long-term paracentesis is indicated for patients with symptoms of increased intraabdominal pressure caused by recurring malignant ascites despite repeated paracentesis.

\section{Recommendation 40}

Permanent catheter drainage should be considered for terminally ill patients with refractory ascites ( $\operatorname{LoE} 4$, GoR C). Broad agreement (94\%).

\section{Sclerotherapy of non-parasitic cysts \\ $\nabla$}

\section{Hepatic cysts}

Hepatic cysts have a prevalence of $2.5-7 \%$. Most are asymptomatic and do not need treatment [198]. Percutaneous treatment, consisting of aspiration of cystic fluid followed by injection of a sclerosing agent, is usually performed with US guidance, as a minimally invasive option for large or symptomatic cysts.

\section{Indications}

Large cysts $(>6-10 \mathrm{~cm}$ ), which are symptomatic (pain or infected) or causing space-occupying effects (abdominal distension, obstructive jaundice or both), require treatment. Other less established indications include symptomatic small sub-capsular cysts located at sites exposed to mechanical stress (beneath the ribs or sternum) [199]. In polycystic liver disease, any cysts may be treated if causing symptoms or to avoid complications (e.g., rupture, bleeding, infection) [200 - 205].

\section{Recommendation 41}

With symptomatic or compressive hepatic cysts, percutaneous sclerotherapy or surgery should be considered (LoE 4, GoR C). Strong consensus (96\%).

\section{Contraindications}

Caution is required when treating hydatid cysts; the nature of a cyst may not be known prior to aspiration [199]. A relative contraindication is hemorrhagic cysts [206] although they can be treated with similar results once infection or malignancy has been excluded [202]. Ascites and planned liver transplantation are other relative contraindications.

\section{Multidisciplinary decision making}

Multidisciplinary decision (gastroenterologists, surgeons, interventional radiologists) for the procedure is mandatory as other options include open surgery and laparoscopic deroofing which are effective treatments. These treatments are associated with substantial morbidity and mortality and require expertise [207, 208]. Percutaneous treatments have similar efficacy, allowing surgery to be reserved for complicated cases or if percutaneous sclerotherapy fails [201, 209].

\section{Sclerotherapy versus surgery (fenestration)}

No randomized prospective study comparing fenestration and sclerotherapy has been published. In most centers, sclerotherapy is attempted first as a noninvasive option, and laparoscopic fenestration is indicated in refractory cases [209]. 


\section{Recommendation 42}

Percutaneous ethanol sclerotherapy is a good alternative to laparoscopic deroofing with similar efficacy and lower complication rates (LoE 4, GoR C). Strong consensus (96\%).

\section{Prognosis}

The majority of patients who undergo percutaneous sclerotherapy are symptomatically improved immediately following the procedure, but only $20 \%$ will have partial or full regression of the dominant and symptomatic cyst [208]. In polycystic liver disease both sclerotherapy and surgery are disappointing (77-100\% recurrence rate) [9].

\section{Materials and technical issues}

The treatment consists of evacuation of the cystic contents (either by aspiration or drainage via a catheter) followed by sclerotherapy of the inner epithelium using standard agents (ethanol, polidocanol, tetracycline chloride, minocycline chloride, hypertonic saline solution and ethanolamine oleate) [210 - 214]. A radiopaque contrast medium or US contrast agent should be instilled into the cyst to exclude a connection with the biliary tree [215]. If contrast medium enters the bile ducts, sclerotherapy is contraindicated.

\section{Ethanol sclerotherapy}

Ethanol (95-98\% concentration) is most commonly used for sclerotherapy of hepatic cysts [216 - 218]. Single or multiple sessions may be needed with evacuation of the fluid content performed using $6-8 \mathrm{~F}$ catheters or a Chiba needle (18-20 gauge) [216 - 218]. After ethanol sclerotherapy, an $80-100 \%$ reduction of cyst volume may be achieved [198, 201, 210, 216, 218, 219]. The main complications during ethanol sclerotherapy are pain, ethanol-induced fever or hyperthermia, intoxication, intra-cystic bleeding and iatrogenic pleurisy or peritonitis [202, 211].

\section{Recommendation $\mathbf{4 3}$}

With percutaneous ethanol sclerotherapy of large liver cysts, the use of small catheters instead of needles should be considered to achieve a longer ethanol exposure time (LoE 4, GoR C). Broad agreement (95\%).

\section{Sclerotherapy using other substances}

Several other substances with better safety profiles, ease of use and low cost have been tested with good results and few complications [210-214]. Polidocanol 1-3\% (aethoxysklerol) may be preferred for its local anesthetic properties (it is less painful than alcohol) and its slight bactericidal activity [199].

\section{Recommendation 44}

Percutaneous sclerotherapy using other substances is an alternative to ethanol (LoE 4, GoR C). Broad agreement (90\%).

\section{Ultrasonographic follow-up}

In polidocanol therapy maximum volume reduction occurred 1 year after the procedure [215]. Follow-up examinations may only be necessary in symptomatic patients.

\section{Renal cysts}

Indications

Simple renal cysts are mostly asymptomatic and do not require treatment. In $2-4 \%$ the cyst may become symptomatic because it enlarges or develops complications such as hemorrhage, infection, rupture or compression [220]. Cysts that develop adjacent to the renal hilum may obstruct the urinary tract [221]. US-guided cyst aspiration with or without sclerosing therapy is a minimally invasive, simple, safe and low-cost procedure [221].

\section{Recommendation 45}

Symptomatic simple renal cysts should be considered for treatment. (LoE 4, GoR C). Broad agreement (94\%).

\section{Multidisciplinary decision making}

A multidisciplinary decision regarding procedure choice is recommended as surgical excision via open, percutaneous, laparoscopic or robotic surgery is effective but more invasive. Laparoscopic deroofing achieves better results than percutaneous sclerotherapy (PS) [220, 221].

\section{Recommendation 46}

The decision on treatment modality should consider that percutaneous sclerotherapy is less invasive and associated with lower risks than laparoscopic deroofing, but has lower efficacy (LoE 2b, GoR B). Broad agreement (88\%).

\section{Materials and technical aspects}

A variety of substances are used for sclerotherapy of the cystic wall [214, $222-231]$ as described for liver cysts.

\section{Simple cyst drainage without sclerotherapy}

After simple aspiration, the recurrence ranges from $30-80 \%$ $[171,232]$.

\section{Recommendation 47}

Simple aspiration should not be used in the treatment of renal cysts because recurrence is frequent ( $\mathrm{LoE} 4$, GoR C). Broad agreement (93\%).

\section{Ethanol sclerotherapy}

The most common sclerotherapy agent for renal cysts is ethanol [227-231]. A concentration of $95-99 \%$ destroys the secreting cells of the cyst wall without affecting the renal parenchyma [220]. Single or multiple sessions have been used, with better results but with higher complications for multiple sessions [221, 228 - 233].

The main complications that may occur during ethanol sclerotherapy are pain, fever, and systemic reactions [220].

\section{Recommendation 48}

Multiple sessions and/or prolonged drainage should be used to reduce recurrence in symptomatic large renal cysts treated with ethanol sclerotherapy (LoE 4, GoR B). Broad agreement (87\%). 


\section{Ultrasonographic follow-up}

Follow-up examinations may only be necessary in symptomatic patients.

\section{Abdominal echinococcal cysts, puncture, aspiration, injection and re-aspiration (PAIR)}

\section{Introduction}

Echinococcosis is a chronic, complex and neglected zoonosis with widespread global distribution. 70\% of cases of cystic echinococcosis (CE) are located in the liver [234]. US has an important role in the diagnosis, treatment and follow-up of abdominal CE and is established in the interventional treatment of abdominal CE $[235,236]$.

\section{Classification}

The WHO echinococcal cyst classification $[237,238]$ is US-based and was introduced to guide treatment options and to predict prognosis [239]. Type CE1 and CE2 are the typical active cysts. Type CE1 is unilocular, whereas CE2 is multilocular with daughter cysts. The Gharbi classification is still widely used [240].

\section{Diagnosis and differential diagnosis}

\section{Imaging}

US is the imaging modality most appropriate for diagnosis and differential diagnosis [238], while US guidance is usually used for intervention $[241,242]$.

\section{Serological tests}

Serological tests for echinococcosis should be obtained, where available, before the procedure $[243,244]$.

\section{PAIR indication}

PAIR is most appropriate for CE1 and CE3a according to the WHO classification (Gharbi type I and II cysts) [244, 245].

\section{Relative contraindications}

Hydatid cysts with multiple daughter cysts and solid components (Gharbi Type III-IV and WHO CE2-CE3b) are not suitable for PAIR $[236,245,246]$. It is reported that aggressive percutaneous evacuation for these complex cysts is useful, but not widely accepted.

\section{Pretreatment procedures}

As with any interventional procedure, the patient should be carefully evaluated before the PAIR procedure. Albendazole should be started one week (or at least one day) prior to the procedure for prophylaxis against abdominal contamination [247], and thereafter continued for at least one month [236, 248].

\section{Procedure, puncture and drainage}

The procedure consists of puncture, aspiration, injection and re-aspiration $[239,249,250]$ using a 20-gauge fine needle $[251,252]$.

\section{Outcome}

RCTs showed PAIR to be superior to albendazole alone [253] and to surgical treatment $[239,254]$. PAIR combined with albendazole was more effective than surgery and was associated with a lower rate of adverse events and a shorter hospital stay. Retro- spective studies favor PAIR over surgery in Gharbi type I and II cysts and found surgical treatment most appropriate in the other Gharbi types [249, 255].

A meta-analysis reported severe adverse events (anaphylaxis, cyst infection, abscess, sepsis, biliary fistula) in $7.9 \%$ of patients treated with PAIR plus albendazole [256].

\section{Recommendation 49}

US-guided PAIR is the most appropriate treatment for WHO CE1 and CE3a abdominal hydatid cysts (LoE 2b, GoR B). Strong consensus $(100 \%)$.

\section{Recommendation 50}

PAIR should always be accompanied by measures to manage possible anaphylaxis (LoE 5, GoR D). Broad agreement (93\%).

\section{Recommendation 51}

Albendazole should be started prior to PAIR (LoE 2b, GoR B). Strong consensus (100\%).

\section{Percutaneous transhepatic cholangiodrainage (PTCD) \\ $\nabla$}

\section{Introduction}

Percutaneous transhepatic cholangiography and drainage (PTCD) is a commonly used procedure for the diagnosis and treatment of benign and malignant biliary diseases [257, 258]. PTCD also allows therapeutic interventions, such as placement of a stent across a malignant stricture, dilatation of benign biliary strictures and extraction of biliary tract stones [259].

\section{Endoscopic retrograde cholangiography versus PTCD} versus endoscopic ultrasound-guided cholangiodrainage Endoscopic retrograde cholangiography (ERC) is the method of choice for patients with indications for (therapeutic) biliary access $[260,261]$. The following surgically altered anatomical situations have a high likelihood for ERC failure: Roux-en-Y with gastric bypass, Kausch-Whipple resection, pylorus-preserving Whipple resection, Roux-en-Y with hepaticojejunostomy, choledochojejunostomy, and pancreaticojejunostomy [262].

Alternative methods are PTCD, EUS-guided interventions (EUS cholangiodrainage, EUS-CD) [192] and balloon-assisted enteroscopy (BAE).

\section{Special problems}

Ultrasound guidance versus fluoroscopic guidance

A blind percutaneous puncture of peripherally located intrahepatic bile ducts has limitations especially with non-dilated bile ducts $[263,264]$. Real-time imaging with US is useful for the guidance of PTCD (US-PTCD), especially in patients with non-dilated ducts and for left-sided PTCD [265 - 267]. Fluoroscopy delivers significant irradiation both to the patient and to the interventional team. The "As Low As Reasonably Achievable" (ALARA) principle should be applied [268]. 


\section{Recommendation 52}

For initial puncture in PTCD ultrasound guidance should be considered (LoE 4, GoR C). Strong consensus (100\%).

\section{Percutaneous cholecystostomy}

$\nabla$

\section{Introduction}

Acute calculous cholecystitis (ACC) is a common cause of acute surgical admission. Early cholecystectomy (CCE) is a widely accepted method of treatment [269]. Laparoscopic cholecystectomy (LCCE) in acute cases has minimal morbidity [270]. In highrisk patients morbidity and mortality increase to $14-46 \%$ [271]. Alternatively, percutaneous cholecystostomy (PC) is a bridging process, especially in otherwise healthy patients (e.g. ASA I and II) who are severely septic and may become fit in due course for semi-elective surgery [272].

\section{Clinical efficacy}

A meta-analysis of 53 studies ( $n=1918$ patients) reported successful PC for $85.6 \%$ of patients. The procedure-related mortality rate of PC was $0.4 \%$ [273].

Evaluation of US-guided percutaneous cholecystostomy (USPC) for patients with acute acalculous cholecystitis (AAC) is more difficult because it is normally a complication of serious medical and surgical illnesses [274, 275]. A study compared clinical efficacy and adverse events of PC and CCE in a large group of severely ill patients with AAC and showed PC to be a safe and cost-effective bridging treatment strategy, with perioperative outcomes superior to those of open CCE. Compared with open or laparascopic CCE $(n=1021), P C(n=704)$ was superior in terms of morbidity, intensive-care unit admissions, length of hospital stay, and costs [276]. Two studies showed that in seriously ill patients with AAC, PC is an effective procedure and may be regarded as a definite treatment option in the majority of patients [277, 278].

Data is limited with respect to the duration of gallbladder drainage. Before removal of the drain, laboratory and clinical data should confirm resolution of sepsis [279]. Patients should be re-evaluated following recovery to assess fitness for elective surgery. Cholecystitis recurrence of $10-30 \%$ is reported, and should be weighed against the mortality and morbidity risk in the individual patient.

\section{Recommendation 53}

Percutaneous ultrasound-guided gallbladder drainage may be considered in patients with acute calculous cholecystitis assessed to be unfit for surgery (LoE 3b, GoR B). Strong consensus $(100 \%)$.

\section{Recommendation 54}

In patients with acute acalculous cholecystitis unfit for surgery, percutaneous ultrasound-guided gallbladder drainage should be considered after diagnostic puncture (LoE 2c, GoR B). Strong consensus (100\%).

\section{Drainage route}

The transhepatic route has advantages regarding tract formation and the avoiding of peritonitis [280, 281]. The transperitoneal approach has been reported to be similar in relation to complica- tions, but formation of a mature tract without leakage as a precondition for catheter removal is significantly delayed compared with the transhepatic approach [280, 282, 283]. EUS-guided transmural gallbladder drainage may be performed as an alternative to USPC [192].

\section{Recommendation 55}

Ultrasound-guided percutaneous gallbladder drainage should be performed transhepatically (LoE 2b, GoR B). Strong consensus $(100 \%)$.

\section{Percutaneous gastrostomy \\ $\nabla$}

\section{Introduction}

Gastrostomy can be offered when oral food uptake is temporarily or permanently compromised. Gastrostomy may be used in patients with neurological disorders (e.g., neurological degeneration) and advanced (oncological) diseases, e. g. in gastrointestinal stenosis with intractable vomiting where surgical treatment is not feasible or is declined. The endoscopic approach (percutaneous endoscopic gastrostomy, PEG) with the "pull" technique is the most common technique.

\section{Image-guided percutaneous gastrostomy (without endo-} scopic access)

The percutaneous approach (image-guided percutaneous gastrostomy, PG) can be performed under fluoroscopy (radiologically inserted gastrostomy, RIG) or US guidance (USPG).

US guidance in experienced hands allows the identification of the position of (a) the stomach, (b) the liver, and (c) in most instances, the transverse colon. Usually the stomach is filled with water by a nasogastric tube, but if US is used to assist endoscopy, air distension is sufficient.

US may be used in the following situations:

- In cases of anticipated difficulty locating the stomach (scars, advanced gastric cancer, obesity, surgically altered stomach anatomy).

- In endoscopic approach when trans-illumination fails.

- In cases without access to the upper gastrointestinal tract (complete esophageal obstruction).

\section{Recommendation 56}

In cases in which conventional endoscopically guided gastric puncture fails, ultrasound-assisted gastric puncture may make it possible to accomplish percutaneous gastrostomy (LoE 4, GoR C). Broad agreement (76\%).

\section{Recommendation 57}

When placing of a nasogastric tube is not possible, the stomach can be punctured under ultrasound guidance and distended with air or water to facilitate percutaneous image-guided gastrostomy (LoE 4, GoR C). Broad agreement (86\%).

Antibiotic prophylaxis is mandatory for PEG using the pull technique for prevention of peristomal infection. For introducer techniques, antibiotic prophylaxis is not necessary. The database for antibiotic prophylaxis in PEG is comprehensive [284]. There is data for RIG showing no wound infections [285]. 


\section{Percutaneous nephrostomy}

\section{Introduction}

Percutaneous nephrostomy (PCN) remains the procedure of choice for temporary drainage of the obstructed collecting system when the transureteral (or retrograde) approach is not indicated or feasible [286, 287]. PCN is also used for urinary diversion and to gain access to the urinary tract for subsequent interventional urologic procedures. PCN can be successfully performed in $95-98 \%$ of patients who have a dilated renal collecting system [250].

\section{Indications and contraindications}

Indications

PCN may be performed for diagnostic or therapeutic purposes [288, 289].

- Relief of urinary obstruction related to malignancy, urinary stones or iatrogenic causes [289].

- Pyonephrosis and obstructive acute pyelonephritis.

- Urinary diversion in patients with urinary fistula, leakage or hemorrhagic cystitis [290, 291].

- Access for endourologic procedures, such as nephrolithotomy and removal of urinary stones, dilation or stenting of a ureteral stricture [288].

- Diagnostic testing, such as antegrade pyelography, ureteral perfusion (Whitaker test) [290].

- Specific situations, e. g., uroenteric diversion.

- Treatment of urolithiasis in transplanted kidneys and external malignant obstruction [292 - 295].

\section{Contraindications}

There is no absolute contraindication for PCN, but the benefits and risks must be weighed for each individual [288, 289]. Relative contraindications are:

- Renal vascular malformations such as an arterial aneurysm [290],

- Severe life-threatening electrolyte imbalances such as hyperkalemia, or severe metabolic acidosis [288],

- Severe coagulopathy [296].

\section{Imaging modalities}

The optimal imaging methods to guide PCN vary at individual centers. The procedure can be performed with the guidance of fluoroscopy, US, CT, and various combinations of those techniques [297-299].

\section{Ultrasound guidance}

US-guided puncture of the collecting system with subsequent placement of the drainage tube under fluoroscopic control is regarded as the standard technique for PCN [290, 300, 301]. US is helpful to identify the most appropriate calyx for puncture and the presence of stones or blood clots or other intraluminal filling defects and to avoid damage to surrounding organs [302]. In addition, it is an ideal method for patient follow-up [302].

\section{Recommendation 58}

Percutaneous nephrostomy can be effectively performed under ultrasound guidance (LoE 2b, GoR B). Strong consensus (100\%).

Injection of US contrast agents via a needle or catheter can also confirm whether the needle or PCN catheter have been correctly inserted in the renal pelvis, with reduction in radiation exposure which may be especially important in the first trimester of pregnancy [303]. Fluoroscopy is recommended to determine the position of the needle and guidewire. The catheter can be visualized by injecting diluted US contrast agent.

\section{Technical aspects and indications}

Methods

\section{Positioning}

The risk of adjacent organ injury during percutaneous nephrostomy is minimized when the nephrostomy is inserted below the 12th rib. Attempts should be made to achieve catheter placement through a calyx, particularly if percutaneous nephrolithotomy or other large-bore catheter placement is considered [290].

\section{Seldinger or trocar technique}

US-guided PCN tube placement has a success rate of $92-94 \%$ $[304,305]$. The trocar and Seldinger techniques are equally effective [306].

\section{Size}

A 6-10F catheter is recommended for PCN. If the collecting system is punctured for further procedures (e.g., tumor or stone removal), a larger catheter may be considered (14-22F).

\section{Recommendation 59}

In percutaneous nephrostomy, access via the posterior-inferior calyces should be attempted to reduce the risk of pleural and vascular injury (LoE 5, GoR D). Strong consensus (100\%).

\section{Post-procedure catheter management and patient care}

Vital signs should be monitored during initial recovery ( $>24$ hours) [288]. Urinary output should be charted. Urine will be blood-tinged initially but prolonged hematuria ( $>24-48$ hours) should serve as an alert to persistent bleeding from vascular injury $[288,307]$. Long-term indwelling catheters should be changed every $4-6$ weeks [250].

\section{Complications}

The incidence of major complications ranges from $0-8 \%$ [286, $299,308,309]$. Minor complications occur in $2-38 \%[286,299$, 308, 309].

\section{Suprapubic puncture of the bladder}

\section{Introduction}

Suprapubic puncture of the bladder is a safe and reliable method to drain the bladder, while avoiding urethral catheterization [310]. US guidance improves the success rate [311-314].

US is recommended to assess the position and volume of the bladder, and to avoid the inadvertent puncture of other structures [ 315 , 316].

\section{Recommendation 60}

Puncture and drainage of the urinary bladder should be performed under ultrasound guidance (LoE 1b, GoR B). Strong consensus $(100 \%)$ 


\section{Main indications}

Suprapubic puncture of the bladder is indicated in pathological conditions of the bladder, prostate or urethra that require temporary or permanent drainage of the bladder when urethral catheterization is not possible or is contraindicated.

\section{Contraindications to the percutaneous US-guided procedure \\ - Absence of visualization of the bladder on US. \\ - Uncorrected coagulopathy.}

- Other relative contraindications are those secondary to complex anatomy due to congenital disorders, habitus, previous surgery or infiltrative pelvic cancer.

\section{Materials and technical problems}

The procedure is performed under sterile conditions after the administration of local anesthesia. Sedation may be useful in select cases. The position and volume of the bladder are identified by US and US is used for real-time guidance of the percutaneous puncture $[315,316]$. Catheters are placed by either the Seldinger or the trocar technique, with dilation of the percutaneous track when necessary. Catheters of $10 \mathrm{~F}$ are large enough to relieve acute urinary retention. Large catheters ( $>16 \mathrm{~F}$ ) are recommended in patients who require prolonged drainage of the bladder in circumstances such as bladder rupture or complicated urethral stricture [310].

\section{Complications}

US guidance can decrease the complication rate of suprapubic puncture [310, 314, 317]. Major complications are rare and include perforation of intestinal loops [318]. Minor complications include pain, infection, hemorrhage, blockage, hematuria and catheter misplacement, all of which are less common when US guidance is performed $[314,317,319]$.

\section{Palliative care \\ $\nabla$}

Palliative care patients often have alterations in locoregional anatomy, vascular patterns and coagulation factors. Therefore, for any invasive procedure it is recommended to consider US guidance to improve safety and help minimize complications and patient discomfort. There are no contraindications of US-guided procedures in palliative care [320]. The management of cancer complications indicates potential roles for home-performed US and US-guided procedures at the end of life [321].

\section{Affiliations}

1 Department of Internal Medicine 2, Caritas Krankenhaus, Bad Mergentheim, Germany

2 Department of Gastric Surgery, Ultrasound Section, Herlev Hospital, University of Copenhagen, Denmark

${ }^{3}$ Department of Radiology, Hadassah Hebrew University Medical Center, Jerusalem, Israel

${ }^{4}$ Department of Gastroenterology and Endoscopy, Ospedale Maggiore Crema, Italy

5 Department of Radiological Sciences, Oncology and Pathology, Policlinico Umberto I, Univ. Sapienza, Rome, Italy

${ }^{6}$ Department of Adult Radiology, Paris-Descartes University and Necker University Hospital, Paris, and Institut Langevin - Inserm U979, Paris, France

7 Sino-German Research Center of Ultrasound in Medicine, The First Affiliated Hospital of Zhengzhou University, Zhengzhou, China

${ }^{8}$ Department of Radiology, GB Rossi University Hospital, University of Verona, Italy

${ }^{9}$ National Centre for Ultrasound in Gastroenterology, Haukeland University Hospital, Bergen Norway and Department of Clinical Medicine, University of Bergen, Norway

${ }^{10}$ Department of Internal Medicine 2, Helios Hospital Meiningen GmbH, Meiningen, Germany

11 Department of Internal Medicine, Krankenhaus Märkisch Oderland Strausberg/Wriezen, Germany

12 Department of Radiology, Akdeniz University Medical Faculty, Antalya, Turkey

13 Imperial College London and Imaging Department, Hammersmith Hospital Campus, London, UK

14 Radiology Department, Hospital Clinic, Barcelona, Spain

${ }^{15}$ Diagnostic Radiology Institute, Paula Stradins Clinical University Hospital, Riga, Latvia

${ }^{16}$ Diagnostic and Interventional Ultrasound Unit, Department of Organ Failure and Transplantation, S. Orsola-Malpighi Hospital Bologna, Italy

17 Department of Radiology, King's College Hospital, London, UK

18 Department of Gastroenterology, Institute for Gastroenterology and Hepatology, University of Medicine and Pharmacy, "Iuliu Hatieganu" Cluj-Napoca, Institute for Gastroenterology and Hepatology "O.Fodor" Cluj-Napoca, Romania

19 Unit of Internal Medicine, Department of Medical and Surgical Sciences, University of Bologna, Bologna, Italy

\section{Acknowledgement}

$\nabla$

The authors kindly thank David Cosgrove (UK), Barbara Braden (UK), Liliana Chiorean (France), Franca Meloni (Italy), Andrej Potthoff (Germany), Klaus Schlottmann (Germany), Wolf B. Schwerk (Germany), and Trygve Syversveen (Norway). We would like to acknowledge the endless support and advice from Lynne Rudd, EFSUMB general secretary.

\section{References}

1 Lorentzen T, Nolsoe CP, Ewertsen C et al. EFSUMB Guidelines on Interventional Ultrasound, Part I: General Aspects. Ultraschall in Med 2015; 36: 464-472

2 Sidhu PS, Bradbrand K, Cantisani V et al. EFSUMB Guidelines on Interventional Ultrasound (INVUS), Part II: Diagnostic Ultrasound Guided Interventional Procedures. Ultraschall in Med 2015, in press

3 Jenssen C, Hocke M, Fusaroli P et al. EFSUMB Guidelines on Interventional Ultrasound (INVUS), Part IV: EUS-guided Interventions: General Aspects and EUS-guided Sampling. Ultraschall in Med 2015, in press

4 Fusaroli P, Jenssen C, Hocke $M$ et al. EFSUMB INVUS Guidelines, Part V: EUS-guided Therapeutic Interventions. Ultraschall in Med 2015, in press

5 Jenssen C, Brkljacic B, Hocke $M$ et al. EFSUMB Guidelines on Interventional Ultrasound (INVUS), Part VI: Ultrasound-Guided Vascular Interventions. Ultraschall in Med 2015, in Press

6 Dietrich CF, Lorentzen T, Sidhu PS et al. An introduction into the EFSUMB guidelines on interventional ultrasound. Ultraschall in Med 2015; 36: 460-463

7 Claudon M, Dietrich CF, Choi BI et al. Guidelines and good clinical practice recommendations for contrast enhanced ultrasound (CEUS) in the liver-update 2012: a WFUMB-EFSUMB initiative in cooperation with representatives of AFSUMB, AIUM, ASUM, FLAUS and ICUS. Ultraschall in Med 2013; 34: 11 - 29

8 Claudon M, Dietrich CF, Choi BI et al. Guidelines and good clinical practice recommendations for Contrast Enhanced Ultrasound (CEUS) in the liver - update 2012: A WFUMB-EFSUMB initiative in cooperation with representatives of AFSUMB, AIUM, ASUM, FLAUS and ICUS. Ultrasound Med Biol 2013; 39: 187-210

9 Dietrich CF, Cui XW, Chiorean L et al. Local ablative procedures of the liver. Z Gastroenterol 2015; 53: 579-590

10 Gillams A, Goldberg N, Ahmed M et al. Thermal ablation of colorectal liver metastases: a position paper by an international panel of ablation experts, the interventional oncology sans frontieres meeting 2013. Eur Radiol 2015

11 Dietrich CF, Albrecht T, Bernatik T et al. Lokal ablative Verfahren von Lebertumoren; Radiofrequenzablation (RFA). In: Dietrich CF, Nurnberg D eds. Interventionelle Sonografie. Thieme Verlag; 2011: 264-282 
12 Dietrich CF, Braden B, Hocke M. Lokal ablative Verfahren, Perkutane Alkoholinjektion. In: Dietrich CF, Nurnberg D eds. Interventionelle Sonografie. Thieme Verlag; 2011: 257-263

13 Ebert MP, Auernhammer C, Caca K et al. Gastrointestinal oncology therapy update 2008 / 2009. Z Gastroenterol 2009; 47: 296-306

14 Greten TF, Malek NP, Schmidt S et al. Diagnosis of and therapy for hepatocellular carcinoma. Z Gastroenterol 2013; 51: 1269-1326

15 Abi-Jaoudeh N, Duffy AG, Greten TF et al. Personalized oncology in interventional radiology. J Vasc Interv Radiol 2013; 24: 1083-1092

16 Vivarelli M, Guglielmi A, Ruzzenente A et al. Surgical resection versus percutaneous radiofrequency ablation in the treatment of hepatocellular carcinoma on cirrhotic liver. Ann Surg 2004; 240: 102-107

17 Ruzzenente A, Guglielmi A, Sandri M et al. Surgical resection versus local ablation for HCC on cirrhosis: results from a propensity case-matched study. J Gastrointest Surg 2012; 16: 301 - 311

18 Dietrich CF, Braden B. Perkutane Zystensklerosierung. In: Dietrich $C F$, Nuernberg D eds. Interventionelle Sonografie. Thieme; 2011: 233 -239

19 Carrafiello G, Lagana D, Cotta E et al. Radiofrequency ablation of intrahepatic cholangiocarcinoma: preliminary experience. Cardiovasc Intervent Radiol 2010; 33: 835-839

20 Mazziotti A, Grazi GL, Gardini A et al. An appraisal of percutaneous treatment of liver metastases. Liver Transpl Surg 1998; 4: $271-275$

21 Ploeckinger U, Kloeppel G, Wiedenmann B et al. The German NET-registry: an audit on the diagnosis and therapy of neuroendocrine tumors. Neuroendocrinology 2009; 90: 349 - 363

22 Auernhammer CJ, Jauch KW, Hoffmann JN. Liver metastases from neuroendocrine tumours of the gastroenteropancreatic system-therapeutic strategies. Zentralbl Chir 2009; 134: 410-417

23 Atwell TD, Charboneau JW, Que FG et al. Treatment of neuroendocrine cancer metastatic to the liver: the role of ablative techniques. Cardiovasc Intervent Radiol 2005; 28: 409 - 421

24 Siperstein $A E$, Berber E. Cryoablation, percutaneous alcohol injection, and radiofrequency ablation for treatment of neuroendocrine liver metastases. World J Surg 2001; 25: 693-696

25 Illing $R$, Gillams $A$. Radiofrequency ablation in the treatment of breast cancer liver metastases. Clin Oncol (R Coll Radiol) 2010; 22: 781 - 784

26 Solbiati L, Ahmed M, Cova $L$ et al. Small liver colorectal metastases treated with percutaneous radiofrequency ablation: local response rate and long-term survival with up to 10-year follow-up. Radiology 2012; 265: 958 - 968

27 Meloni MF, Andreano A, Laeseke PF et al. Breast cancer liver metastases: US-guided percutaneous radiofrequency ablation-intermediate and long-term survival rates. Radiology 2009; 253: 861 - 869

28 Nikfarjam M, Shereef S, Kimchi ET et al. Survival outcomes of patients with colorectal liver metastases following hepatic resection or ablation in the era of effective chemotherapy. Ann Surg Oncol 2009; 16 : $1860-1867$

29 Pox C, Schmiegel W, Reinacher-Schick A. Colorectal carcinoma: what's new? Dtsch Med Wochenschr 2012; 137: 2577-2580

30 Pox C, Aretz S, Bischoff SC et al. S3-guideline colorectal cancer version 1.0. Z Gastroenterol 2013; 51: $753-854$

31 Miller G, Biernacki P, Kemeny NE et al. Outcomes after resection of synchronous or metachronous hepatic and pulmonary colorectal metastases. J Am Coll Surg 2007; 205: 231 - 238

32 Adam R, Avisar E, Ariche A et al. Five-year survival following hepatic resection after neoadjuvant therapy for nonresectable colorectal. Ann Surg Oncol 2001; 8: $347-353$

33 Abdalla EK, Vauthey JN. Chemotherapy prior to hepatic resection for colorectal liver metastases: helpful until harmful? Dig Surg 2008; 25: $421-429$

34 Abdalla EK. Commentary: Radiofrequency ablation for colorectal liver metastases: do not blame the biology when it is the technology. Am J Surg 2009; 197: $737-739$

35 Evrard S, Poston G, Kissmeyer-Nielsen P et al. Combined Ablation and Resection (CARe) as an Effective Parenchymal Sparing Treatment for Extensive Colorectal Liver Metastases. PLoS One 2014; 9: e114404

36 Livraghi T, Solbiati L, Meloni F et al. Percutaneous radiofrequency ablation of liver metastases in potential candidates for resection: the "testof-time approach". Cancer 2003; 97: 3027 - 3035

37 Rossi S, Di Stasi M, Buscarini E et al. Percutaneous radiofrequency interstitial thermal ablation in the treatment of small hepatocellular carcinoma. Cancer I Sci Am 1995; 1: 73 - 81

38 Livraghi T, Goldberg SN, Lazzaroni S et al. Small hepatocellular carcinoma: treatment with radio-frequency ablation versus ethanol injection. Radiology 1999; 210: 655-661
39 Shiina S, Teratani T, Obi S et al. Nonsurgical treatment of hepatocellular carcinoma: from percutaneous ethanol injection therapy and percutaneous microwave coagulation therapy to radiofrequency ablation. Oncology 2002; 62: 64-68

40 Sugiura $N$, Takara K, Ohto $M$ et al. Percutaneous intratumoral injection of ethanol under ultrasound imaging for treatment of small hepatocellular carcinoma. Acta Hepatol Jpn 1983; 24: 920

41 Livraghi T, Festi D, Monti F et al. US-guided percutaneous alcohol injection of small hepatic and abdominal tumors. Radiology 1986; 161: $309-312$

42 Shiina S, Tagawa K, Niwa Y et al. Percutaneous ethanol injection therapy for hepatocellular carcinoma: results in 146 patients. Am J Roentgenol 1993; 160: 1023 -1028

43 Seki T, Wakabayashi M, Nakagawa T et al. Ultrasonically guided percutaneous microwave coagulation therapy for small hepatocellular carcinoma. Cancer 1994; 74: 817-825

44 Mazzaferro $V$, Regalia E, Doci R et al. Liver transplantation for the treatment of small hepatocellular carcinomas in patients with cirrhosis. $\mathrm{N}$ Engl J Med 1996; 334: 693 - 699

45 Omata M, Lesmana LA, Tateishi R et al. Asian Pacific Association for the Study of the Liver consensus recommendations on hepatocellular carcinoma. Hepatol Int 2010; 4: 439-474

46 Seror O, N'Kontchou G, Ibraheem $M$ et al. Large (>or=5.0-cm) HCCs: multipolar RF ablation with three internally cooled bipolar electrodes-initial experience in 26 patients. Radiology 2008; 248: $288-296$

47 N'Kontchou G, Mahamoudi A, Aout $M$ et al. Radiofrequency ablation of hepatocellular carcinoma: long-term results and prognostic factors in 235 Western patients with cirrhosis. Hepatology 2009; 50: 1475 - 1483

48 Chen $M H$, Yang $W$, Yan $K$ et al. Large liver tumors: protocol for radiofrequency ablation and its clinical application in 110 patients-mathematic model, overlapping mode, and electrode placement process. Radiology 2004; 232: 260-271

49 Bale R, Widmann G, Haidu M. Stereotactic Radiofrequency Ablation. Cardiovasc Intervent Radiol 2010

50 Sainani NI, Gervais DA, Mueller PR et al. Imaging after percutaneous radiofrequency ablation of hepatic tumors: Part 1, Normal findings. Am J Roentgenol 2013; 200: 184-193

51 Komorizono $Y$, Oketani $M$, Sako $K$ et al. Risk factors for local recurrence of small hepatocellular carcinoma tumors after a single session, single application of percutaneous radiofrequency ablation. Cancer 2003; 97 $1253-1262$

52 Imamura J, Tateishi $R$, Shiina $S$ et al. Neoplastic seeding after radiofrequency ablation for hepatocellular carcinoma. Am J Gastroenterol 2008; 103: $3057-3062$

53 Llovet JM, Vilana $R, B r u C$ et al. Increased risk of tumor seeding after percutaneous radiofrequency ablation for single hepatocellular carcinoma. Hepatology 2001; 33: 1124 - 1129

54 Teratani $T$, Yoshida H, Shiina S et al. Radiofrequency ablation for hepatocellular carcinoma in so-called high-risk locations. Hepatology 2006; 43: $1101-1108$

55 Ritz JP, Lehmann K, Isbert C et al. Effectivity of laser-induced thermotherapy: in vivo comparison of arterial microembolization and complete hepatic inflow occlusion. Lasers Surg Med 2005; 36: 238 - 244

56 Kim SW, Rhim H, Park M et al. Percutaneous radiofrequency ablation of hepatocellular carcinomas adjacent to the gallbladder with internally cooled electrodes: assessment of safety and therapeutic efficacy. Korean J Radiol 2009; 10: 366 - 376

57 Kang TW, Rhim H, Kim EY et al. Percutaneous radiofrequency ablation for the hepatocellular carcinoma abutting the diaphragm: assessment of safety and therapeutic efficacy. Korean J Radiol 2009; 10: 34-42

58 Head HW, Dodd GD III, Dalrymple NC et al. Percutaneous radiofrequency ablation of hepatic tumors against the diaphragm: frequency of diaphragmatic injury. Radiology 2007; 243: 877 - 884

59 Abdalla EK, Vauthey JN, Ellis LM et al. Recurrence and outcomes following hepatic resection, radiofrequency ablation, and combined resection/ ablation for colorectal liver metastases. Ann Surg 2004; 239: 818 - 825

60 Wang Y, Luo Q Li Y et al. Radiofrequency ablation versus hepatic resection for small hepatocellular carcinomas: a meta-analysis of randomized and nonrandomized controlled trials. PLoS One 2014; 9: e84484

61 Goldberg SN, Kamel IR, Kruskal JB et al. Radiofrequency ablation of hepatic tumors: increased tumor destruction with adjuvant liposomal doxorubicin therapy. Am J Roentgenol 2002; 179: 93-101

62 Shirato K, Morimoto M, Tomita $N$ et al. Small hepatocellular carcinoma: therapeutic effectiveness of percutaneous radio frequency ablation therapy with a LeVeen needle electrode. J Ultrasound Med 2002; 21: 67 - 76 
63 Rossi S, Buscarini E, Garbagnati F et al. Percutaneous treatment of small hepatic tumors by an expandable RF needle electrode. Am J Roentgenol 1998; 170: 1015-1022

64 Cucchetti A, Piscaglia F, Cescon M et al. Systematic review of surgical resection vs radiofrequency ablation for hepatocellular carcinoma. World J Gastroenterol 2013; 19: 4106-4118

65 Weis S, Franke A, Mossner J et al. Radiofrequency (thermal) ablation versus no intervention or other interventions for hepatocellular carcinoma. Cochrane Database Syst Rev 2013; 12: CD003046

66 Cucchetti A, Piscaglia F, Cescon M et al. An explorative data-analysis to support the choice between hepatic resection and radiofrequency ablation in the treatment of hepatocellular carcinoma. Dig Liver Dis 2014; 46: $257-263$

67 Lencioni R, Cioni D, Crocetti L et al. Early-stage hepatocellular carcinoma in patients with cirrhosis: long-term results of percutaneous image-guided radiofrequency ablation. Radiology 2005; 234: 961 - 967

68 Tateishi R, Shiina S, Teratani T et al. Percutaneous radiofrequency ablation for hepatocellular carcinoma. An analysis of 1000 cases. Cancer 2005; 103: 1201 - 1209

69 Cabassa P, Donato F, Simeone F et al. Radiofrequency ablation of hepatocellular carcinoma: long-term experience with expandable needle electrodes. Am J Roentgenol 2006; 186: S316-S321

70 Livraghi T, Meloni F, Di Stasi M et al. Sustained complete response and complications rates after radiofrequency ablation of very early hepatocellular carcinoma in cirrhosis: Is resection still the treatment of choice? Hepatology 2008; 47: 82 - 89

71 Yan $K$, Chen $M H$, Yang $W$ et al. Radiofrequency ablation of hepatocellular carcinoma: long-term outcome and prognostic factors. Eur J Radiol 2008; 67: 336-347

72 Kasugai H, Osaki Y, Oka H et al. Severe complications of radiofrequency ablation therapy for hepatocellular carcinoma: an analysis of $3891 \mathrm{ab}-$ lations in 2614 patients. Oncology 2007; 72: $72-75$

73 Shiina S, Tagawa K, Unuma T et al. Percutaneous ethanol injection therapy for hepatocellular carcinoma. A histopathologic study. Cancer 1991; 68: $1524-1530$

74 Sung YM, Choi D, Lim HK et al. Long-term results of percutaneous ethanol injection for the treatment of hepatocellular carcinoma in Korea. Korean J Radiol 2006; 7: 187-192

75 Livraghi T, Giorgio A, Marin G et al. Hepatocellular carcinoma and cirrhosis in 746 patients: long-term results of percutaneous ethanol injection. Radiology 1995; 197: $101-108$

76 Dietrich $C F$, Hocke $M$, Jenssen $C$. Ultrasound for abdominal lymphadenopathy. Dtsch Med Wochenschr 2013; 138: 1001 - 1018

77 Brunello $F$, Veltri A, Carucci $P$ et al. Radiofrequency ablation versus ethanol injection for early hepatocellular carcinoma: A randomized controlled trial. Scand J Gastroenterol 2008; 43: 727-735

78 Lencioni RA, Allgaier HP, Cioni D et al. Small hepatocellular carcinoma in cirrhosis: randomized comparison of radio-frequency thermal ablation versus percutaneous ethanol injection. Radiology 2003; 228 : $235-240$

79 Lin SM, Lin CJ, Lin CC et al. Randomised controlled trial comparing percutaneous radiofrequency thermal ablation, percutaneous ethanol injection, and percutaneous acetic acid injection to treat hepatocellular carcinoma of $3 \mathrm{~cm}$ or less. Gut 2005; 54: 1151 - 1156

80 Shiina S, Teratani T, Obi S et al. A randomized controlled trial of radiofrequency ablation with ethanol injection for small hepatocellular carcinoma. Gastroenterology 2005; 129: 122 - 130

81 Lin SM, Lin CJ, Lin CC et al. Radiofrequency ablation improves prognosis compared with ethanol injection for hepatocellular carcinoma $<$ or $=4$ cm. Gastroenterology 2004; 127: 1714-1723

82 Orlando A, Leandro $G$, Olivo $M$ et al. Radiofrequency thermal ablation vs. percutaneous ethanol injection for small hepatocellular carcinoma in cirrhosis: meta-analysis of randomized controlled trials. Am J Gastroenterol 2009; 104: 514-524

83 Yang B, Zan RY, Wang SY et al. Radiofrequency ablation versus percutaneous ethanol injection for hepatocellular carcinoma: a meta-analysis of randomized controlled trials. World J Surg Oncol 2015; 13: 96

84 Cho YK, Kim JK, Kim MY et al. Systematic review of randomized trials for hepatocellular carcinoma treated with percutaneous ablation therapies. Hepatology 2009; 49: 453-459

85 Giorgio A, Di Sarno A, De Stefano G et al. Percutaneous radiofrequency ablation of hepatocellular carcinoma compared to percutaneous ethanol injection in treatment of cirrhotic patients: an Italian randomized controlled trial. Anticancer Res 2011; 31: 2291 - 2295
86 Germani G, Pleguezuelo M, Gurusamy $K$ et al. Clinical outcomes of radiofrequency ablation, percutaneous alcohol and acetic acid injection for hepatocelullar carcinoma: a meta-analysis. J Hepatol 2010; 52: $380-388$

87 Bouza C, Lopez-Cuadrado T, Alcazar R et al. Meta-analysis of percutaneous radiofrequency ablation versus ethanol injection in hepatocellular carcinoma. BMC Gastroenterol 2009; 9: 31

88 Omata M, Tateishi R, Yoshida H et al. Treatment of hepatocellular carcinoma by percutaneous tumor ablation methods: Ethanol injection therapy and radiofrequency ablation. Gastroenterology 2004; 127: S159-S166

89 Sala M, Llovet JM, Vilana $R$ et al. Initial response to percutaneous ablation predicts survival in patients with hepatocellular carcinoma. Hepatology 2004; 40: 1352 - 1360

90 Guglielmi A, Ruzzenente A, Valdegamberi A et al. Radiofrequency ablation versus surgical resection for the treatment of hepatocellular carcinoma in cirrhosis. J Gastrointest Surg 2008; 12: 192-198

91 Liang $P$, Dong B, Yu X et al. Prognostic factors for survival in patients with hepatocellular carcinoma after percutaneous microwave ablation. Radiology 2005; 235: 299 - 307

92 Liang $P$, Wang Y. Microwave ablation of hepatocellular carcinoma. Oncology 2007; 72: 124-131

93 Liang $P$, Wang $Y, Y u$ X et al. Malignant liver tumors: treatment with percutaneous microwave ablation-complications among cohort of 1136 patients. Radiology 2009; 251: 933 - 940

94 Lu MD, Xu HX, Xie XY et al. Percutaneous microwave and radiofrequency ablation for hepatocellular carcinoma: a retrospective comparative study. J Gastroenterol 2005; 40: 1054-1060

95 Ohmoto K, Miyake I, Tsuduki M et al. Percutaneous microwave coagulation therapy for unresectable hepatocellular carcinoma. Hepatogastroenterology 1999; 46: 2894-2900

96 Sato $M$, Watanabe $Y$, Ueda $S$ et al. Microwave coagulation therapy for hepatocellular carcinoma. Gastroenterology 1996; 110: 1507-1514

97 Yin XY, Xie XY, Lu MD et al. Percutaneous thermal ablation of medium and large hepatocellular carcinoma: long-term outcome and prognostic factors. Cancer 2009; 115: 1914-1923

98 Ebara M, Okabe S, Kita K et al. Percutaneous ethanol injection for small hepatocellular carcinoma: therapeutic efficacy based on 20-year observation. J Hepatol 2005; 43: 458-464

99 Khan KN, Yatsuhashi $H$, Yamasaki $K$ et al. Prospective analysis of risk factors for early intrahepatic recurrence of hepatocellular carcinoma following ethanol injection. J Hepatol 2000; 32: 269-278

100 Koda M, Murawaki Y, Mitsuda A et al. Predictive factors for intrahepatic recurrence after percutaneous ethanol injection therapy for small hepatocellular carcinoma. Cancer 2000; 88: 529-537

101 Pompili M, Rapaccini GL, Covino M et al. Prognostic factors for survival in patients with compensated cirrhosis and small hepatocellular carcinoma after percutaneous ethanol injection therapy. Cancer 2001; 92: $126-135$

102 Kim YJ, Lee MW, Park HS. Small hepatocellular carcinomas: ultrasonography guided percutaneous radiofrequency ablation. Abdom Imaging 2013; 38: $98-111$

103 Rajesh S, Mukund A, Arora A et al. Contrast-enhanced US-guided radiofrequency ablation of hepatocellular carcinoma. J Vasc Interv Radiol 2013; 24: 1235 - 1240

104 Choi D, Lim HK, Lee WJ et al. Early assessment of the therapeutic response to radio frequency ablation for hepatocellular carcinoma: utility of gray scale harmonic ultrasonography with a microbubble contrast agent. J Ultrasound Med 2003; 22: 1163 -1172

105 Minami $Y$, Kudo M, Chung $H$ et al. Contrast harmonic sonographyguided radiofrequency ablation therapy versus B-mode sonography in hepatocellular carcinoma: prospective randomized controlled trial. Am J Roentgenol 2007; 188: 489-494

106 Takaki H, Yamakado K, Nakatsuka A et al. Frequency of and risk factors for complications after liver radiofrequency ablation under CT fluoroscopic guidance in 1500 sessions: single-center experience. Am J Roentgenol 2013; 200: 658-664

107 Evrard S, Brouste V, McKelvie-Sebileau P et al. Liver metastases in close contact to hepatic veins ablated under vascular exclusion. Eur J Surg Oncol 2013; 39: 1400-1406

108 Desolneux G, Vara J, Razafindratsira T et al. Patterns of complications following intraoperative radiofrequency ablation for liver metastases. HPB (Oxford) 2014; 16: 1002 - 1008 
109 Schwartz A, Desolneux G, Desjardin M et al. Symptomatic diaphragmatic hernia after pulmonary radiofrequency ablation. J Visc Surg 2013; 150: $157-158$

110 Curley SA. Radiofrequency ablation of malignant liver tumors. Oncologist 2001; 6: 14-23

111 Livraghi T, Solbiati L, Meloni MF et al. Treatment of focal liver tumors with percutaneous radio-frequency ablation: complications encountered in a multicenter study. Radiology 2003; 226: 441-451

112 de Baère T, Risse 0 , Kuoch V et al. Adverse events during radiofrequency treatment of 582 hepatic tumors. Am J Roentgenol 2003; 181: $695-700$

113 Jenssen C, Dietrich CF. Kontraindikationen, Komplikationen, Komplikationsmanagment. In: Dietrich CF, Nuernberg D eds. Interventionelle Sonografie. Thieme Verlag; 2011: 127-160

114 Arienti V, Pretolani S, Goldberg SN et al. How to report and compare complications of image-guided ablation therapies: comments on seeding and the use of a sole common denominator for liver tumors. Radiology 2006; 241: 625-626

115 Chang S, Kim SH, Lim HK et al. Needle tract implantation after percutaneous interventional procedures in hepatocellular carcinomas: lessons learned from a 10-year experience. Korean J Radiol 2008; 9: $268-274$

116 Livraghi T, Lazzaroni S, Meloni $F$ et al. Risk of tumour seeding after percutaneous radiofrequency ablation for hepatocellular carcinoma. Br J Surg 2005; 92: 856-858

117 Bolondi L, Gaiani S, Celli $N$ et al. Tumor dissemination after radiofrequency ablation of hepatocellular carcinoma. Hepatology 2001; 34: $608-601$

118 Kanas GP, Taylor A, Primrose JN et al. Survival after liver resection in metastatic colorectal cancer: review and meta-analysis of prognostic factors. Clin Epidemiol 2012; 4: 283 - 301

119 Bradley AL, Chapman WC, Wright JK et al. Surgical experience with hepatic colorectal metastasis. Am Surg 1999; 65: 560-566

120 Doci R, Gennari L, Bignami P et al. One hundred patients with hepatic metastases from colorectal cancer treated by resection: analysis of prognostic determinants. Br J Surg 1991; 78: 797-801

121 Fong $Y$, Fortner J, Sun RL et al. Clinical score for predicting recurrence after hepatic resection for metastatic colorectal cancer: analysis of 1001 consecutive cases. Ann Surg 1999; 230: 309-318

122 Ohlsson B, Stenram U, Tranberg KG. Resection of colorectal liver metastases: 25-year experience. World J Surg 1998; 22: 268 - 276

123 Scheele J, Stangl R, Altendorf-Hofmann A et al. Indicators of prognosis after hepatic resection for colorectal secondaries. Surgery 1991; 110 : $13-29$

124 Wagner JS, Adson MA, Van Heerden JA et al. The natural history of hepatic metastases from colorectal cancer. A comparison with resective treatment. Ann Surg 1984; 199: 502 - 508

125 Neumann UP, Seehofer D, Neuhaus P. The surgical treatment of hepatic metastases in colorectal carcinoma. Dtsch Arztebl Int 2010; 107: $335-342$

126 Park IJ, Kim HC, Yu CS et al. Radiofrequency ablation for metachronous liver metastasis from colorectal cancer after curative surgery. Ann Surg Oncol 2008; 15: 227-232

127 Lorentzen T, Skjoldbye BO, Nolsoe CP. Microwave ablation of liver metastases guided by contrast-enhanced ultrasound: experience with 125 metastases in 39 patients. Ultraschall in Med 2011; 32: 492 - 496

128 Cho YK, Kim JK, Kim WT et al. Hepatic resection versus radiofrequency ablation for very early stage hepatocellular carcinoma: a Markov model analysis. Hepatology 2010; 51: 1284-1290

129 Lee WS, Yun SH, Chun HK et al. Clinical outcomes of hepatic resection and radiofrequency ablation in patients with solitary colorectal liver metastasis. J Clin Gastroenterol 2008; 42: 945 - 949

130 Gillams AR, Lees WR. Five-year survival in 309 patients with colorectal liver metastases treated with radiofrequency ablation. Eur Radiol 2009; 19: 1206-1213

131 Gillams AR, Lees WR. Radio-frequency ablation of colorectal liver metastases in 167 patients. Eur Radiol 2004; 14: 2261 - 2267

132 Knudsen AR, Kannerup AS, Mortensen FV et al. Radiofrequency ablation of colorectal liver metastases downstaged by chemotherapy. Acta Radiol 2009; 50: 716-721

133 Tanis E, Nordlinger B, Mauer M et al. Local recurrence rates after radiofrequency ablation or resection of colorectal liver metastases. Analysis of the European Organisation for Research and Treatment of Cancer \#40004 and \#40983. Eur J Cancer 2014; 50: 912-919
134 Weng M, Zhang Y, Zhou D et al. Radiofrequency ablation versus resection for colorectal cancer liver metastases: a meta-analysis. PLoS One 2012; 7: e45493

135 Bai H, Huangz X, Jing $L$ et al. The effect of radiofrequency ablation vs. liver resection on survival outcome of colorectal liver metastases (CRLM): a meta-analysis. Hepatogastroenterology 2015; 62: 373-377

136 Ruers T, Punt C, van Coevorden F et al. Radiofrequency ablation combined with systemic treatment versus systemic treatment alone in patients with non-resectable colorectal liver metastases: a randomized EORTC Intergroup phase II study (EORTC 40004). Ann Oncol 2012; 23: 2619-2626

137 Remzi M, Javadli E, Ozsoy M. Management of small renal masses: a review. World J Urol 2010; 28: 275 - 281

138 Aron M, Gill IS. Minimally invasive nephron-sparing surgery (MINSS) for renal tumours. Part II: probe ablative therapy. Eur Urol 2007; 51: $348-357$

139 Nahum GS, Dupuy DE. Image-guided radiofrequency tumor ablation: challenges and opportunities-part I. J Vasc Interv Radiol 2001; 12: $1021-1032$

140 Gervais DA, McGovern FJ, Arellano RS et al. Radiofrequency ablation of renal cell carcinoma: part 1, Indications, results, and role in patient management over a 6-year period and ablation of 100 tumors. Am J Roentgenol 2005; 185: 64-71

141 Gervais DA, Arellano RS, McGovern FJ et al. Radiofrequency ablation of renal cell carcinoma: part 2, Lessons learned with ablation of 100 tumors. Am J Roentgenol 2005; 185: $72-80$

142 Tracy CR, Raman JD, Donnally C et al. Durable oncologic outcomes after radiofrequency ablation: experience from treating 243 small renal masses over 7.5 years. Cancer 2010; 116: $3135-3142$

143 Zagoria RJ, Traver MA, Werle DM et al. Oncologic efficacy of CT-guided percutaneous radiofrequency ablation of renal cell carcinomas. Am J Roentgenol 2007; 189: 429-436

144 Breen DJ, Rutherford EE, Stedman B et al. Management of renal tumors by image-guided radiofrequency ablation: experience in 105 tumors. Cardiovasc Intervent Radiol 2007; 30: 936-942

145 Levinson AW, Su LM, Agarwal D et al. Long-term oncological and overall outcomes of percutaneous radio frequency ablation in high risk surgical patients with a solitary small renal mass. J Urol 2008; 180 $499-504$

146 Stein RJ, KaoukJH. Renal cryotherapy: a detailed review including a 5year follow-up. BJU Int 2007; 99: 1265-1270

147 Atwell TD, Callstrom MR, Farrell MA et al. Percutaneous renal cryoablation: local control at mean 26 months of followup. J Urol 2010; 184: 1291 - 1295

148 Atwell TD, Farrell MA, Callstrom MR et al. Percutaneous cryoablation of large renal masses: technical feasibility and short-term outcome. Am J Roentgenol 2007; 188: 1195 - 1200

149 Klatte T, Kroeger N, Zimmermann U et al. The contemporary role of ablative treatment approaches in the management of renal cell carcinoma (RCC): focus on radiofrequency ablation (RFA), high-intensity focused ultrasound (HIFU), and cryoablation. World J Urol 2014; 32: $597-605$

150 El DibR, Touma NJ, Kapoor A. Cryoablation vs radiofrequency ablation for the treatment of renal cell carcinoma: a meta-analysis of case series studies. BJU Int 2012; 110: 510-516

151 Goel RK, Kaouk JH. Probe ablative treatment for small renal masses: cryoablation vs. radio frequency ablation. Curr Opin Urol 2008; 18: 467-473

152 Wah TM, Irving HC, Gregory W et al. Radiofrequency ablation (RFA) of renal cell carcinoma (RCC): experience in 200 tumours. BJU Int 2014; 113: $416-428$

153 Goldberg SN, Grassi CJ, Cardella JF et al. Image-guided tumor ablation: standardization of terminology and reporting criteria. J Vasc Interv Radiol 2009; 20: S377-S390

154 Campbell SC, Novick AC, Belldegrun A et al. Guideline for management of the clinical T1 renal mass. J Urol 2009; 182: 1271 -1279

155 Psutka SP, Feldman AS, McDougal WS et al. Long-term oncologic outcomes after radiofrequency ablation for T1 renal cell carcinoma. Eur Urol 2013; 63: 486-492

156 Kunkle DA, Egleston BL, Uzzo RG. Excise, ablate or observe: the small renal mass dilemma-a meta-analysis and review. J Urol 2008; 179: $1227-1233$

157 Ljungberg B, Cowan NC, Hanbury DC et al. EAU guidelines on renal cell carcinoma: the 2010 update. Eur Urol 2010; 58: 398-406 
158 Meloni MF, Bertolotto M, Alberzoni C et al. Follow-up after percutaneous radiofrequency ablation of renal cell carcinoma: contrast-enhanced sonography versus contrast-enhanced CT or MRI. Am J Roentgenol 2008; 191: $1233-1238$

159 Kong WT, Zhang WW, Guo HQ et al. Application of contrast-enhanced ultrasonography after radiofrequency ablation for renal cell carcinoma: is it sufficient for assessment of therapeutic response? Abdom Imaging 2011; 36: $342-347$

160 Ignee $A$, Straub B, Brix D et al. The value of contrast enhanced ultrasound (CEUS) in the characterisation of patients with renal masses. Clin Hemorheol Microcirc 2010; 46: 275-290

161 Ignee A, Straub B, Schuessler G et al. Contrast enhanced ultrasound of renal masses. World J Radiol 2010; 2: 15-31

162 Smith EH, Bartrum RJ Jr. Ultrasonically guided percutaneous aspiration of abscesses. Am J Roentgenol Radium Ther Nucl Med 1974; 122: $308-312$

163 Wittmann $D H$, Schein $M$, Condon RE. Management of secondary peritonitis. Ann Surg 1996; 224: $10-18$

164 Kishina M, Koda M, Tokunaga S et al. Usefulness of contrast-enhanced ultrasound with Sonazoid for evaluating liver abscess in comparison with conventional B-mode ultrasound. Hepatol Res 2014

165 Liu GJ, Lu MD, Xie XY et al. Real-time contrast-enhanced ultrasound imaging of infected focal liver lesions. J Ultrasound Med 2008; 27 : $657-666$

166 Cai YL, Xiong XZ, Lu J et al. Percutaneous needle aspiration versus catheter drainage in the management of liver abscess: a systematic review and meta-analysis. HPB (Oxford) 2014

167 Zerem E, Hadzic A. Sonographically guided percutaneous catheter drainage versus needle aspiration in the management of pyogenic liver abscess. Am J Roentgenol 2007; 189: W138 - W142

168 Zerem E, Bergsland J. Ultrasound guided percutaneous treatment for splenic abscesses: the significance in treatment of critically ill patients. World J Gastroenterol 2006; 12: 7341 - 7345

169 Lorentzen T, Nolsoe C, Skjoldbye B. Ultrasound-guided drainage of deep pelvic abscesses: experience with 33 cases. Ultrasound Med Biol 2011; 37: $723-728$

170 Schwerk WB, Gorg C, Gorg K et al. Percutaneous drainage of liver and splenic abscess. Z Gastroenterol 1991; 29: 146-152

171 Schwerk WB, Gorg C, Gorg K et al. Ultrasound-guided percutaneous drainage of pyogenic splenic abscesses. J Clin Ultrasound 1994; 22: $161-166$

172 Rothlin MA, Schob O, Klotz H et al. Percutaneous drainage of abdominal abscesses: are large-bore catheters necessary? Eur J Surg 1998; 164: $419-424$

173 Cui XW, Ignee A, Dietrich CF. Ultrasound-guided percutaneous abscess drainage. In. http://www.efsumb.org/asp/detail06.asp?ref=373\&url=/ intro/home.asp?ref=1: European Federation of Societies for Ultrasound in Medicine and Biology; 2011

174 Ignee A, Schuessler G, Cui XW et al. Intracavitary contrast medium ultrasound - different applications, a review of the literature ad future prospects. Ultraschall in Med 2013; 34: 504-525; quiz 526-508

175 Ignee A, Jenssen C, Cui XW et al. Intracavitary contrast-enhanced ultrasound in abscess drainage - feasibility and clinical value. Scand J Gastroenterol 2015: 1 - 7

176 Pham Van L, Duong Manh H, Pham Nhu H. Amebic abscess of the liver: ultrasound guided puncture. Ann Chir 1996; 50: 340 - 343

177 McInnes MD, Kielar AZ, Macdonald DB. Percutaneous image-guided biopsy of the spleen: systematic review and meta-analysis of the complication rate and diagnostic accuracy. Radiology 2011; 260: 699- 708

178 Feagins LA, Holubar SD, Kane SV et al. Current strategies in the management of intra-abdominal abscesses in Crohn's disease. Clin Gastroenterol Hepatol 2011; 9: 842-850

179 Gervais DA, Hahn PF, O'Neill MJ et al. Percutaneous abscess drainage in Crohn disease: technical success and short- and long-term outcomes during 14 years. Radiology 2002; 222: 645 - 651

180 Golfieri R, Cappelli A, Giampalma E et al. CT-guided percutaneous pelvic abscess drainage in Crohn's disease. Tech Coloproctol 2006; 10: 99- 105

181 Sahai A, Belair M, Gianfelice D et al. Percutaneous drainage of intraabdominal abscesses in Crohn's disease: short and long-term outcome. Am J Gastroenterol 1997; 92: 275 - 278

182 da Luz Moreira A, Stocchi L, Tan E et al. Outcomes of Crohn's disease presenting with abdominopelvic abscess. Dis Colon Rectum 2009; 52: $906-912$
183 Rypens F, Dubois J, Garel L et al. Percutaneous drainage of abdominal abscesses in pediatric Crohn's disease. Am J Roentgenol 2007; 188: 579-585

184 Bahadursingh AM, Virgo KS, Kaminski DL et al. Spectrum of disease and outcome of complicated diverticular disease. Am J Surg 2003; 186: $696-701$

185 Siewert B, Tye G, Kruskal J et al. Impact of CT-guided drainage in the treatment of diverticular abscesses: size matters. Am J Roentgenol 2006; 186: $680-686$

186 Brandt D, Gervaz P, Durmishi Y et al. Percutaneous CT scan-guided drainage vs. antibiotherapy alone for Hinchey II diverticulitis: a case-control study. Dis Colon Rectum 2006; 49: 1533-1538

187 Kumar RR, Kim JT, Haukoos JS et al. Factors affecting the successful management of intra-abdominal abscesses with antibiotics and the need for percutaneous drainage. Dis Colon Rectum 2006; 49: 183 189

188 Kaiser AM, Jiang JK, Lake JP et al. The management of complicated diverticulitis and the role of computed tomography. Am J Gastroenterol 2005; 100: 910 - 917

189 Durmishi Y, Gervaz P, Brandt D et al. Results from percutaneous drainage of Hinchey stage II diverticulitis guided by computed tomography scan. Surg Endosc 2006; 20: 1129-1133

190 Kuligowska E, Keller E, Ferrucci JT. Treatment of pelvic abscesses: value of one-step sonographically guided transrectal needle aspiration and lavage. Am J Roentgenol 1995; 164: 201 - 206

191 Wroblicka JT, Kuligowska E. One-step needle aspiration and lavage for the treatment of abdominal and pelvic abscesses. Am J Roentgenol 1998; 170: 1197 - 1203

192 Fusaroli $P$, Jenssen $C$, Hocke $M$ et al. EFSUMB guidelines on interventional ultrasound, part V. EUS-guided therapeutic interventions. Ultraschall in Med 2015; 36

193 Mercaldi CJ, Lanes SF. Ultrasound guidance decreases complications and improves the cost of care among patients undergoing thoracentesis and paracentesis. Chest 2013; 143: $532-538$

194 Sharzehi K, Jain V, Naveed A et al. Hemorrhagic complications of paracentesis: a systematic review of the literature. Gastroenterol Res Pract 2014; 2014: 985141

195 Cervini $P$, Hesley GK, Thompson RL et al. Incidence of infectious complications after an ultrasound-guided intervention. Am J Roentgenol 2010; 195: $846-850$

196 Cavanna L, Mordenti P, Berte $R$ et al. Ultrasound guidance reduces pneumothorax rate and improves safety of thoracentesis in malignant pleural effusion: report on 445 consecutive patients with advanced cancer. World J Surg Oncol 2014; 12: 139

197 Sangisetty SL, Miner TJ. Malignant ascites: A review of prognostic factors, pathophysiology and therapeutic measures. World J Gastrointest Surg 2012; 4: 87-95

198 Zerem E, Imamovic G, Omerovic S. Percutaneous treatment of symptomatic non-parasitic benign liver cysts: single-session alcohol sclerotherapy versus prolonged catheter drainage with negative pressure. Eur Radiol 2008; 18: 400-406

199 Dietrich CF, Braden B. Percutaneous Sclerotherapy of Cysts. In: Dietrich CF, Nuernberg D eds. Interventional ultrasound. Stuttgart: Georg Thieme Verlag /Thieme Publisher; 2014: 165-166

200 Garber S, Mathieson J, Cooperberg PL. Percutaneous sclerosis of hepatic cysts to treat obstructive jaundice in a patient with polycystic liver disease. Am J Roentgenol 1993; 161: 77-78

201 Erdogan D, van Delden OM, Rauws EA et al. Results of percutaneous sclerotherapy and surgical treatment in patients with symptomatic simple liver cysts and polycystic liver disease. World J Gastroenterol 2007; 13: $3095-3100$

202 Benzimra J, Ronot M, Fuks D et al. Hepatic cysts treated with percutaneous ethanol sclerotherapy: time to extend the indications to haemorrhagic cysts and polycystic liver disease. Eur Radiol 2014; 24: $1030-1038$

203 Gevers TJ, Drenth JP. Diagnosis and management of polycystic liver disease. Nat Rev Gastroenterol Hepatol 2013; 10: 101-108

204 Temmerman F, Missiaen L, Bammens B et al. Systematic review: the pathophysiology and management of polycystic liver disease. Aliment Pharmacol Ther 2011; 34: $702-713$

205 Macutkiewicz C, Plastow R, Chrispijn M et al. Complications arising in simple and polycystic liver cysts. World J Hepatol 2012; 4: 406-411

206 Fong ZV, Wolf AM, Doria C et al. Hemorrhagic hepatic cyst: report of a case and review of the literature with emphasis on clinical approach and management. J Gastrointest Surg 2012; 16: 1782 - 1789 
207 Furuta T, Yoshida Y, Saku M et al. Treatment of symptomatic nonparasitic liver cysts-surgical treatment versus alcohol injection therapy. HPB Surg 1990; 2: 269-277; discussion 277-269

208 Drenth JP, Chrispijn M, Nagorney DM et al. Medical and surgical treatment options for polycystic liver disease. Hepatology 2010; 52: $2223-2230$

209 Moorthy K, Mihssin N, Houghton PW. The management of simple hepatic cysts: sclerotherapy or laparoscopic fenestration. Ann R Coll Surg Engl 2001; 83: 409-414

210 Yang CF, Liang HL, Pan HB et al. Single-session prolonged alcohol-retention sclerotherapy for large hepatic cysts. Am J Roentgenol 2006; 187: $940-943$

211 Fabrizzi G, Lanza C, Bolli V et al. Symptomatic hepatic cyst in a child: treatment with single-shot injection of tetracycline hydrochloride. Pediatr Radiol 2009; 39: 1091 - 1094

212 Yoshida H, Onda M, Tajiri T et al. Long-term results of multiple minocycline hydrochloride injections for the treatment of symptomatic solitary hepatic cyst. J Gastroenterol Hepatol 2003; 18: 595-598

213 Jusufovic R, Zerem E. Percutaneous treatment of symptomatic nonparasitic benign liver cysts with $20 \% \mathrm{NaCl}$ solution. Med Arh 2011; 65: $35-37$

214 Yamamoto K, Sakaguchi H, Anai H et al. Sclerotherapy for simple cysts with use of ethanolamine oleate: preliminary experience. Cardiovasc Intervent Radiol 2005; 28: 751 - 755

215 Sparchez Z, Radu P, Zaharie F et al. Percutaneous treatment of symptomatic non-parasitic hepatic cysts. Initial experience with singlesession sclerotherapy with polidocanol. Med Ultrason 2014; 16: $222-228$

216 vanSonnenberg E, Wroblicka JT, D'Agostino HB et al. Symptomatic hepatic cysts: percutaneous drainage and sclerosis. Radiology 1994; 190: $387-392$

217 Tikkakoski T, Makela JT, Leinonen S et al. Treatment of symptomatic congenital hepatic cysts with single-session percutaneous drainage and ethanol sclerosis: technique and outcome. J Vasc Interv Radiol 1996; 7: $235-239$

218 Larssen TB, Jensen DK, Viste A et al. Single-session alcohol sclerotherapy in symptomatic benign hepatic cysts. Long-term results. Acta Radiol 1999; 40: 636-638

219 Larssen TB, Rosendahl K, Horn A et al. Single-session alcohol sclerotherapy in symptomatic benign hepatic cysts performed with a time of exposure to alcohol of 10 min: initial results. Eur Radiol 2003; 13: $2627-2632$

220 Skolarikos A, Laguna MP, de la Rosette JJ. Conservative and radiological management of simple renal cysts: a comprehensive review. BJU Int 2012; 110: $170-178$

221 Okeke AA, Mitchelmore AE, Keeley FX et al. A comparison of aspiration and sclerotherapy with laparoscopic de-roofing in the management of symptomatic simple renal cysts. BJU Int 2003; 92: 610-613

222 Ohta S, Fujishiro Y, Fuse H. Polidocanol sclerotherapy for simple renal cysts. Urol Int 1997; 58: 145-147

223 Yoo KH, Lee SJ, Jeon SH. Simple renal cyst sclerotherapy with acetic acid: our 10-year experience. J Endourol 2008; 22: 2559-2563

224 Madeb R, Feldman PA, Knopf J et al. Povidone-iodine sclerotherapy is ineffective in the treatment of symptomatic renal cysts. J Endourol 2006; 20: $402-404$

225 Kilinc M, Tufan O, Guven S et al. Percutaneous injection sclerotherapy with tetracycline hydrochloride in simple renal cysts. Int Urol Nephrol 2008; 40: 609-613

226 Ohkawa M, Tokunaga S, Orito $M$ et al. Percutaneous injection sclerotherapy with minocycline hydrochloride for simple renal cysts. Int Urol Nephrol 1993; 25: $37-43$

227 Zerem E, Imamovic G, Omerovic S. Symptomatic simple renal cyst: comparison of continuous negative-pressure catheter drainage and single-session alcohol sclerotherapy. Am J Roentgenol 2008; 190: $1193-1197$

228 Mohsen T, Gomha MA. Treatment of symptomatic simple renal cysts by percutaneous aspiration and ethanol sclerotherapy. BJU Int 2005; 96: $1369-1372$

229 Delakas D, Karyotis I, Loumbakis Pet al. Long-term results after percutaneous minimally invasive procedure treatment of symptomatic simple renal cysts. Int Urol Nephrol 2001; 32: 321 - 326

230 Chung $\mathrm{BH}$, Kim JH, Hong $\mathrm{CH}$ et al. Comparison of single and multiple sessions of percutaneous sclerotherapy for simple renal cyst. BJU Int 2000; 85: $626-627$
231 Fontana D, Porpiglia F, Morra I et al. Treatment of simple renal cysts by percutaneous drainage with three repeated alcohol injection. Urology 1999; 53: $904-907$

232 Hanna RM, Dahniya MH. Aspiration and sclerotherapy of symptomatic simple renal cysts: value of two injections of a sclerosing agent. Am J Roentgenol 1996; 167: 781 - 783

233 Egilmez H, Gok V, Oztoprak I et al. Comparison of CT-guided sclerotherapy with using 95\% ethanol and 20\% hypertonic saline for managing simple renal cyst. Korean J Radiol 2007; 8: 512 - 519

234 McManus DP, Zhang W, Li J et al. Echinococcosis. Lancet 2003; 362: $1295-1304$

235 Stojkovic M, Rosenberger K, Kauczor HU et al. Diagnosing and staging of cystic echinococcosis: how do CT and MRI perform in comparison to ultrasound? PLoS Negl Trop Dis 2012; 6: e1880

236 Brunetti E, Kern P, Vuitton DA et al. Expert consensus for the diagnosis and treatment of cystic and alveolar echinococcosis in humans. Acta Trop 2010; 114: 1 - 16

237 Guidelines for treatment of cystic and alveolar echinococcosis in humans. WHO Informal Working Group on Echinococcosis. Bull World Health Organ 1996; 74: $231-242$

238 Group WHOIW. International classification of ultrasound images in cystic echinococcosis for application in clinical and field epidemiological settings. Acta Trop 2003; 85: 253 - 261

239 Khuroo MS, Wani NA, Javid G et al. Percutaneous drainage compared with surgery for hepatic hydatid cysts. N Engl J Med 1997; 337: 881 887

240 Gharbi HA, Hassine W, Brauner MW et al. Ultrasound examination of the hydatic liver. Radiology 1981; 139: 459-463

241 Ben Amor N, Gargouri M, Gharbi HA et al. Trial therapy of inoperable abdominal hydatid cysts by puncture. Ann Parasitol Hum Comp 1986 61: 689-692

242 Gargouri M, Ben Amor N, Ben Chehida F et al. Percutaneous treatment of hydatid cysts (Echinococcus granulosus). Cardiovasc Intervent Radiol 1990; 13: 169-173

243 Zhang W, Li J, McManus DP. Concepts in immunology and diagnosis of hydatid disease. Clin Microbiol Rev 2003; 16: 18-36

244 Rinaldi F, Brunetti E, Neumayr A et al. Cystic echinococcosis of the liver: A primer for hepatologists. World J Hepatol 2014; 6: 293-305

245 Junghanss T, da Silva AM, Horton J et al. Clinical management of cystic echinococcosis: state of the art, problems, and perspectives. Am J Trop Med Hyg 2008; 79: $301-311$

246 Giorgio A, de Stefano $G$, Esposito $V$ et al. Long-term results of percutaneous treatment of hydatid liver cysts: a single center 17 years experience. Infection 2008; 36: 256-261

247 Akhan 0 , Yildiz AE, Akinci $D$ et al. Is the adjuvant albendazole treatment really needed with PAIR in the management of liver hydatid cysts? A prospective, randomized trial with short-term follow-up results. Cardiovasc Intervent Radiol 2014; 37: 1568-1574

248 Brunetti E, Junghanss T. Update on cystic hydatid disease. Curr Opin Infect Dis 2009; 22: 497-502

249 Kabaalioglu A, Ceken K, Alimoglu E et al. Percutaneous imaging-guided treatment of hydatid liver cysts: do long-term results make it a first choice? Eur J Radiol 2006; 59: 65 - 73

250 Dietrich CF, Nuernberg D. Interventional Ultrasound: A Practical Guide and Atlas. Stuttgart, New York, Delhi, Rio: Thieme publisher; 2014

251 Giorgio A, Tarantino L, de Stefano G et al. Hydatid liver cyst: an 11-year experience of treatment with percutaneous aspiration and ethanol injection. J Ultrasound Med 2001; 20: 729-738

252 Giorgio A, Di Sarno A, de Stefano G et al. Sonography and clinical outcome of viable hydatid liver cysts treated with double percutaneous aspiration and ethanol injection as first-line therapy: efficacy and long-term follow-up. Am J Roentgenol 2009; 193: W186-W192

253 Khuroo MS, Dar MY, Yattoo GN et al. Percutaneous drainage versus albendazole therapy in hepatic hydatidosis: a prospective, randomized study. Gastroenterology 1993; 104: 1452 - 1459

254 Nasseri-Moghaddam S, Abrishami A, Taefi A et al. Percutaneous needle aspiration, injection, and re-aspiration with or without benzimidazole coverage for uncomplicated hepatic hydatid cysts. Cochrane Database Syst Rev 2011, CD003623

255 Gupta N, Javed A, Puri S et al. Hepatic hydatid: PAIR, drain or resect? J Gastrointest Surg 2011; 15: 1829-1836

256 Smego RA Jr, Bhatti S, Khaliq AA et al. Percutaneous aspiration-injection-reaspiration drainage plus albendazole or mebendazole for hepatic cystic echinococcosis: a meta-analysis. Clin Infect Dis 2003; 37: $1073-1083$ 
257 Cozzi G, Severini A, Civelli E et al. Percutaneous transhepatic biliary drainage in the management of postsurgical biliary leaks in patients with nondilated intrahepatic bile ducts. Cardiovasc Intervent Radiol 2006; 29: $380-388$

258 Nagino M, Takada T, Miyazaki $M$ et al. Preoperative biliary drainage for biliary tract and ampullary carcinomas. J Hepatobiliary Pancreat Surg 2008; 15: 25 - 30

259 Kavanagh PV, vanSonnenberg E, Wittich GR et al. Interventional radiology of the biliary tract. Endoscopy 1997; 29: 570-576

260 Adler DG, Baron TH, Davila RE et al. ASGE guideline: the role of ERCP in diseases of the biliary tract and the pancreas. Gastrointest Endosc 2005; 62: $1-8$

261 Itoi T, Tsuyuguchi T, Takada T et al. TG13 indications and techniques for biliary drainage in acute cholangitis (with videos). J Hepatobiliary Pancreat Sci 2013; 20: $71-80$

262 Skinner M, Popa D, Neumann H et al. ERCP with the overtube-assisted enteroscopy technique: a systematic review. Endoscopy 2014; 46: $560-572$

263 Kuhn JP, Busemann A, Lerch MM et al. Percutaneous biliary drainage in patients with nondilated intrahepatic bile ducts compared with patients with dilated intrahepatic bile ducts. Am J Roentgenol 2010; 195: $851-857$

264 Weber A, Gaa J, Rosca B et al. Complications of percutaneous transhepatic biliary drainage in patients with dilated and nondilated intrahepatic bile ducts. Eur J Radiol 2009; 72: 412 - 417

265 Lee W, Kim GC, Kim JY et al. Ultrasound and fluoroscopy guided percutaneous transhepatic biliary drainage in patients with nondilated bile ducts. Abdom Imaging 2008; 33: 555 - 559

266 Hayashi N, Sakai T, Kitagawa $M$ et al. US-guided left-sided biliary drainage: nine-year experience. Radiology 1997; 204: 119-122

267 Miyazaki M, Shibuya K, Tokue H et al. Percutaneous transhepatic biliary drainage assisted by real-time virtual sonography: a retrospective study. BMC Gastroenterol 2013; 13: 127

268 Feigenbaum K, Ellett ML, Miller R et al. ALARA study of teaching effectiveness on reducing radiation exposure. Gastroenterol Nurs 1998; 21: $234-238$

269 Gurusamy K, Junnarkar S, Farouk M et al. Meta-analysis of randomized controlled trials on the safety and effectiveness of day-case laparoscopic cholecystectomy. Br J Surg 2008; 95: 161 - 168

270 Gurusamy K, Samraj K, Gluud C et al. Meta-analysis of randomized controlled trials on the safety and effectiveness of early versus delayed laparoscopic cholecystectomy for acute cholecystitis. Br J Surg 2010; 97: 141 - 150

271 Houghton PW, Jenkinson LR, Donaldson LA. Cholecystectomy in the elderly: a prospective study. Br J Surg 1985; 72: 220-222

272 Sanjay P, Mittapalli D, Marioud A et al. Clinical outcomes of a percutaneous cholecystostomy for acute cholecystitis: a multicentre analysis. HPB (Oxford) 2013; 15: 511 - 516

273 Winbladh A, Gullstrand P, Svanvik J et al. Systematic review of cholecystostomy as a treatment option in acute cholecystitis. HPB (Oxford) 2009; 11: $183-193$

274 Johanning JM, Gruenberg JC. The changing face of cholecystectomy. Am Surg 1998; 64: 643-647; discussion 647-648

275 Barie PS, Eachempati SR. Acute acalculous cholecystitis. Curr Gastroenterol Rep 2003; 5: 302 - 309

276 Simorov A, Ranade A, Parcells J et al. Emergent cholecystostomy is superior to open cholecystectomy in extremely ill patients with acalculous cholecystitis: a large multicenter outcome study. Am J Surg 2013; 206: 935 - 940; discussion 940-931

277 Chung YH, Choi ER, Kim KM et al. Can percutaneous cholecystostomy be a definitive management for acute acalculous cholecystitis? J Clin Gastroenterol 2012; 46: 216-219

278 Kirkegard J, Horn T, Christensen SD et al. Percutaneous Cholecystostomy is an Effective Definitive Treatment Option for Acute Acalculous Cholecystitis. Scand J Surg 2015

279 Melloul E, Denys A, Demartines N et al. Percutaneous drainage versus emergency cholecystectomy for the treatment of acute cholecystitis in critically ill patients: does it matter? World J Surg 2011; 35: 826 833

280 Hatjidakis AA, Karampekios S, Prassopoulos P et al. Maturation of the tract after percutaneous cholecystostomy with regard to the access route. Cardiovasc Intervent Radiol 1998; 21: 36-40

281 Venara A, Carretier V, Lebigot J et al. Technique and indications of percutaneous cholecystostomy in the management of cholecystitis in 2014. J Visc Surg 2014; 151: 435 - 439
282 van Overhagen H, Meyers H, Tilanus HW et al. Percutaneous cholecystectomy for patients with acute cholecystitis and an increased surgical risk. Cardiovasc Intervent Radiol 1996; 19: 72-76

283 Loberant $N$, Notes $Y$, Eitan A et al. Comparison of early outcome from transperitoneal versus transhepatic percutaneous cholecystostomy. Hepatogastroenterology 2010; 57: $12-17$

284 Lipp A, Lusardi G. Systemic antimicrobial prophylaxis for percutaneous endoscopic gastrostomy. Cochrane Database Syst Rev 2013; 11: CD005571

285 Lowe AS, Laasch HU, Stephenson S et al. Multicentre survey of radiologically inserted gastrostomy feeding tube (RIG) in the UK. Clin Radiol 2012; 67: $843-854$

286 Wah TM, Weston MJ, Irving HC. Percutaneous nephrostomy insertion: outcome data from a prospective multi-operator study at a UK training centre. Clin Radiol 2004; 59: 255 - 261

287 Hausegger KA, Portugaller HR. Percutaneous nephrostomy and antegrade ureteral stenting: technique-indications-complications. Eur Radiol 2006; 16: 2016-2030

288 Mahmood RD, Yizhi L, Tan MLM. Percutaneous Nephrostomy. In: Goeoz M ed. Chronic Kidney Disease. InTech; 2012: 297-314

289 Ramchandani P, Cardella JF, Grassi CJ et al. Quality improvement guidelines for percutaneous nephrostomy. J Vasc Interv Radiol 2003; 14: S277 - S281

290 Dagli M, Ramchandani P. Percutaneous nephrostomy: technical aspects and indications. Semin Intervent Radiol 2011; 28: 424-437

291 Png JC, Chapple CR. Principles of ureteric reconstruction. Curr Opin Urol 2000; 10: 207-212

292 Lapitan MC, Buckley BS. Impact of palliative urinary diversion by percutaneous nephrostomy drainage and ureteral stenting among patients with advanced cervical cancer and obstructive uropathy: a prospective cohort. J Obstet Gynaecol Res 2011; 37: 1061 - 1070

293 Ahmad I, Saeed Pansota M, Tariq M et al. Comparison between Double $\mathrm{J}$ (DJ) Ureteral Stenting and Percutaneous Nephrostomy (PCN) in Obstructive Uropathy. Pak J Med Sci 2013; 29: 725 - 729

294 Wyatt J, Kolettis PN, Burns JR. Treatment outcomes for percutaneous nephrolithotomy in renal allografts. J Endourol 2009; 23: 1821 - 1824

295 Mahdavi $R$, Tavakkoli M, Taghavi $R$ et al. Minimally invasive procedures for treatment of urolithiasis in transplanted kidneys. Exp Clin Transplant 2014; 12: $200-204$

296 Farrell TA, Hicks ME. A review of radiologically guided percutaneous nephrostomies in 303 patients. J Vasc Interv Radiol 1997; 8: 769-774

297 Skolarikos A, Alivizatos G, Papatsoris A et al. Ultrasound-guided percutaneous nephrostomy performed by urologists: 10-year experience. Urology 2006; 68: 495 - 499

298 Kariniemi J, Sequeiros RB, Ojala $R$ et al. MRI-guided percutaneous nephrostomy: a feasibility study. Eur Radiol 2009; 19: 1296-1301

299 Barbaric ZL, Hall T, Cochran ST et al. Percutaneous nephrostomy: placement under CT and fluoroscopy guidance. Am J Roentgenol 1997; 169: 151 - 155

300 Ray CE Jr, Brown AC, Smith MT et al. Percutaneous access of nondilated renal collecting systems. Semin Intervent Radiol 2014; 31: $98-100$

301 Patel U, Hussain FF. Percutaneous nephrostomy of nondilated renal collecting systems with fluoroscopic guidance: technique and results. Radiology 2004; 233: 226-233

302 Fischbach F, Porsch M, Krenzien F et al. MR imaging guided percutaneous nephrostomy using a 1.0 Tesla open MR scanner. Cardiovasc Intervent Radiol 2011; 34: 857-863

303 Cui XW, Ignee A, Maros T et al. The use of ultrasound contrast agent in ultrasound guided percutaneous nephrostomy. In: Lepzig: Z Gastroenterol; 2014: KG264

304 Karim R, Sengupta S, Samanta S et al. Percutaneous nephrostomy by direct puncture technique: An observational study. Indian J Nephrol 2010; 20: 84-88

305 Regalado SP. Emergency percutaneous nephrostomy. Semin Intervent Radiol 2006; 23: $287-294$

306 Cangüven O, Göktafl C, Kafkasl A et al. Comparison of direct and Seldinger percutaneous nephrostomy insertion techniques. BTDMJB 2009; 5: $103-105$

307 Dyer RB, Regan JD, Kavanagh PV et al. Percutaneous nephrostomy with extensions of the technique: step by step. Radiographics 2002; 22: $503-525$

308 Radecka E, Magnusson A. Complications associated with percutaneous nephrostomies. A retrospective study. Acta Radiol 2004; 45: 184-188 
309 LeMaitre L, Mestdagh P, Marecaux-Delomez J et al. Percutaneous nephrostomy: placement under laser guidance and real-time CT fluoroscopy. Eur Radiol 2000; 10: 892 - 895

310 Lee MJ, Papanicolaou N, Nocks BN et al. Fluoroscopically guided percutaneous suprapubic cystostomy for long-term bladder drainage: an alternative to surgical cystostomy. Radiology 1993; 188: 787-789

311 Gochman RF, Karasic RB, Heller MB. Use of portable ultrasound to assist urine collection by suprapubic aspiration. Ann Emerg Med 1991; 20: $631-635$

312 Chu RW, Wong YC, Luk SH et al. Comparing suprapubic urine aspiration under real-time ultrasound guidance with conventional blind aspiration. Acta Paediatr 2002; 91: 512-516

313 Kiernan SC, Pinckert TL, Keszler M. Ultrasound guidance of suprapubic bladder aspiration in neonates. J Pediatr 1993; 123: 789-791

314 Cronin CG, Prakash P, Gervais DA et al. Imaging-guided suprapubic bladder tube insertion: experience in the care of 549 patients. Am J Roentgenol 2011; 196: 182-188
315 Jacob P, Rai BP, Todd AW. Suprapubic catheter insertion using an ultrasound-guided technique and literature review. BJU Int 2012; 110: $779-784$

316 Lawrentschuk N, Lee D, Marriott P et al. Suprapubic stab cystostomy: a safer technique. Urology 2003; 62: 932 -934

317 Aguilera PA, Choi T, Durham BA. Ultrasound-guided suprapubic cystostomy catheter placement in the emergency department. J Emerg Med 2004; 26: 319-321

318 Lamont T, Harrison S, Panesar S et al. Safer insertion of suprapubic catheters: summary of a safety report from the National Patient Safety Agency. BMJ 2011; 342: d924

319 Johnson S, Fiscus G, Sudakoff GS et al. The utility of abdominal ultrasound during percutaneous suprapubic catheter placement. Can J Urol 2013; 20: 6840-6843

320 Requarth J. Image-guided palliative care procedures. Surg Clin North Am 2011; 91: 367-402, ix

321 Mariani PJ, Setla JA. Palliative ultrasound for home care hospice patients. Acad Emerg Med 2010; 17: 293-296 